IDENTIFICATION AND CHARACTERIZATION OF HYDROLOGIC PROPERTIES

OF FRACTURED TUFF USING HYDRAULIC AND TRACER TESTS--

TEST WELL USW H-4, YUCCA MOUNTAIN, NYE COUNTY, NEVADA

By James R. Erickson and Richard K. Waddell

U.S. GEOLOGICAL SURVEY

Water-Resources Investigations Report 85-4066

Prepared in cooperation with the

U.S . DEPARTMENT OF ENERGY

Denver, Colorado

1985 
UNITED STATES DEPARTMENT OF THE INTERIOR

DONALD PAUL HODEL, Secretary

GEOLOGICAL SURVEY

Dallas L. Peck, Director

For additional information

write to:

Chief, Nuclear Hydrology Program

U.S. Geological Survey

Water Resources Division

Box 25406, Mail Stop 416

Denver Federal Center

Denver, Colorado 80225
Copies of this report can be purchased from:

Open-File Services Section Western Distribution Branch U.S. Geological Survey Box 25425, Federal Center Denver, Colorado 80225

Telephone: (303) 236-7476 
CONTENTS

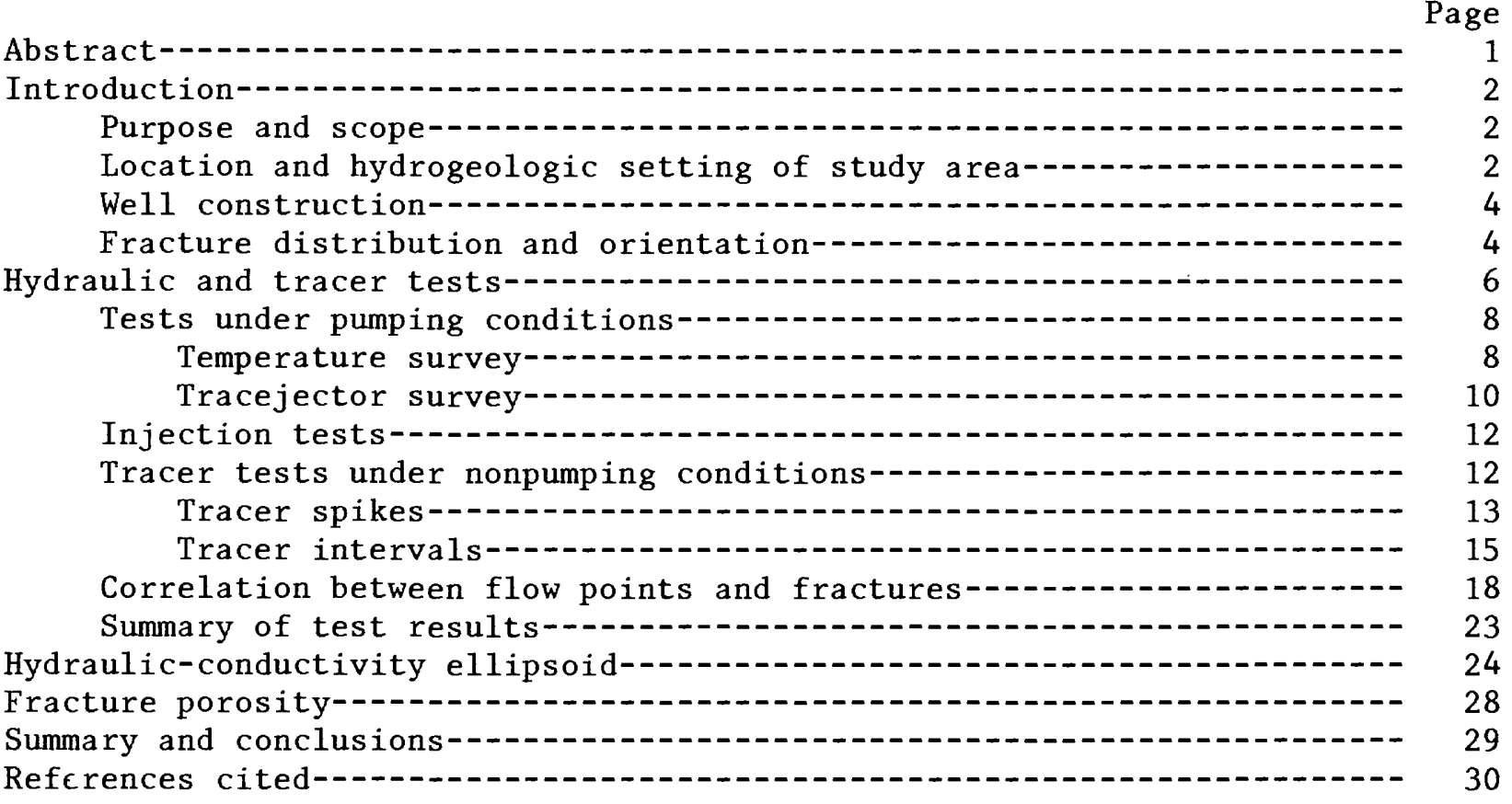

\section{ILLUSTRATIONS}

Plate 1. Plots showing relative activity of tracer and hole diameter for intervals tested by continuous ejection and monitoring of iodine-131, test well USW H-4, Nye County, Nevada--- In pocket

Figure 1. Map showing location of test well USW H-4--

2. Map showing location of faults near test well USW H-4-------

3. Diagram showing location of fractures and flow intervals identified by tracejector survey, temperature surveys, injection tests, and static-tracer tests in test well USW $\mathrm{H}-4---1---1$

4. Diagram showing hypothetical temperature profiles in a borehole with upward-moving water being produced at various

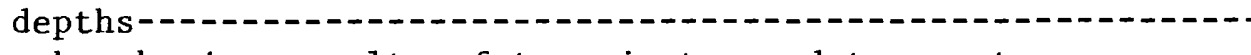

5. Graphs showing results of tracejector and temperature surveys while pumping test well USW H-4---

6. Graph showing comparison between the first and second logging runs through a continuous-tracer interval in test well USW H-4-1.--

7. Lower hemisphere, equal-area stereographic plot of fractures identified by acoustic-televiewer $10 \mathrm{~g}$ in test well USW H-4 and the plane containing the two major principal hydraulicconductivity axes for equal-and nonequal-aperture cases---- 


\section{TABLES}

Table 1. Summary of tracer-spike velocities and flow rates---na-ne---

2. Correlation of flow points, identified from temperature log obtained during pumping, with fractures identified from acoustic-televiewer and television-camera logs-----19

3. Ratio of principal hydraulic-conductivity values for fractures in USW H-4, as determined by the Snow equation----.-- 26

4. Estimates of fracture porosity of tuffs penetrated by USW H-4, assuming the 33 flow zones are equally permeable----

\section{METRIC CONVERSION TABLE}

Multiply inch-pound units

cubic foot per hour $\left(\mathrm{ft}^{3} / \mathrm{h}\right)$

foot $(\mathrm{ft})$

foot per hour $(\mathrm{ft} / \mathrm{h})$

gallon per minute (gal/min)

inch (in.)

mile (mi)
$B y$

0.02832

0.3048

0.3048

3.785

25.40

1.609
To obtain SI units

cubic meter per hour meter

meter per hour liter per minute millimeter kilometer 


\title{
IDENTIFICATION AND CHARACTERIZATION OF HYDROLOGIC PROPERTIES OF FRACTURED TUFF USING HYDRAULIC AND TRACER TESTS--TEST WELL USW H-4, YUCCA MOUNTAIN, NYE COUNTY, NEVADA
}

By James R. Erickson and Richard K. Waddell

\begin{abstract}
Test well USW H-4, located on the eastern edge of Yucca Mountain, Nye County, Nevada, penetrates volcanic tuffs through which water moves primarily along fractures. Data collected from hydrologic and tracer tests and an acoustic-televiewer $\log$, were used to quantify intrawell-bore flow directions and rates, permeability distribution, fracture porosity, and orientations of the hydraulic-conductivity ellipsoid for the test well. The majority (86.2 percent) of the total fractures detected in the test well with the acoustic-televiewer $\log$ have strikes ranging from north $10^{\circ}$ west to north $55^{\circ}$ east and dips ranging from $50^{\circ}$ to $86^{\circ}$, whereas 5.7 percent of the fractures strike from north $15^{\circ}$ west to north $55^{\circ}$ west. Borehole temperature data collected during a pumping test were used to identify 33 locations at which water was entering the hole. These results correlated well with results from radioactive-tracer surveys and packer tests of isolated intervals.

Iodine-131 was used as a tracer under nonpumping conditions to study flow within the borehole, and to identify fractures that produced or accepted water. Water within the borehole was moving down from above and up from below toward the interval between 2,500 and 3,070 feet. Inflow and outflow were detected in the two most permeable zones in the borehole (both inflow and outflow from 2,365 to 2,385 feet, and inflow from 3,880 to 4,000 feet); however, the nondetection of it in the other test intervals may have resulted from monitoring periods that were too short. In the uppermost permeable zone, water moved down from above 2,365 feet and exited the borehole between 2,365 to 2,375 feet; freshwater entered the borehole between 2,380 and 2,385 feet and moved downward.

The probable shape and orientation of the hydraulic-conductivity ellipsoid was calculated from fracture frequency and orientation data. The plane containing the two larger principal axes of the ellipsoid strikes approximately north $23^{\circ}$ east and is nearly vertical. These two axes are approximately the same magnitude and are five to seven times larger than the smallest axis. Fracture porosity is about $10^{-4}$ to $10^{-3}$, as estimated from the cubic law for hydraulic conductivity of fractures.
\end{abstract}




\section{INTRODUCTION}

The U.S. Geological Survey has been conducting geologic and hydrologic investigations of Yucca Mountain in Nye County, Nev., to evaluate the area for the potential subsurface disposal of high-level nuclear waste. The investigations are part of the Nevada Nuclear Waste Storage Investigations project being conducted in cooperation with the U.S. Department of Energy, Nevada Operations Office, under Interagency Agreement DE-AI08-78ET44802. The identification, quantification, and correlation of zones of major ground-water flow are an integral part of these investigations.

\section{Purpose and Scope}

The purpose of this report is to present results and interpretations of hydrologic and tracer tests used to identify and characterize fractures contributing to ground-water flow in test well USW H-4 near Yucca Mountain. In addition, based on geophysical logs, the hydraulic-conductivity ellipsoid and fracture porosity were estimated. This report also presents an approach to identifying individual fractures and fracture zones affecting intrawell-bore flow. Intrawell-bore flow velocities were measured at seven locations in USW H-4 using a short-duration radioactive tracer. More permeable fractures were identified using temperature and borehole-flow surveys while the hole was being pumped. These fractures were correlated with fractures mapped with an acoustic-televiewer log of the hole. The probable range of orientations of the principal permeability tensor for the fractures penetrated by test well USW H-4 was determined using a technique developed by Snow (1969).

\section{Location and Hydrogeologic Setting of Study Area}

Test well USW H-4 is adjacent to the western boundary of the Nevada Test Site in Nye County, Nev., about $87 \mathrm{mi}$ northwest of Las Vegas (fig. 1). The well is in an easterly draining canyon of Yucca Mountain, west of Jackass Flats.

The Yucca Mountain site is underlain by a thick sequence of Tertiary ashflow and ash-fall tuffs, intercalated with thin beds of lava and bedded tuffs, unconformably deposited on a Paleozoic bedrock surface. Three principal source areas exist for these tuffs and lavas: Crater Flat-Prospector Pass caldera about $5 \mathrm{mi}$ west of Yucca Mountain (Carr and others, 1984), the Timber Mountain-Oasis Valley cauldron complex about $10 \mathrm{mi}$ north of Yucca Mountain, and the northwestern part of Calico Hills about $5 \mathrm{mi}$ northeast of Yucca Mountain (Maldonado and Koether, 1983).

Test well USW H-4 penetrated 4,000 ft of ash-flow and bedded tuff. The formations penetrated in the hole, from land surface to total depth, consisted of the following: Paintbrush Tuff, rhyolite lava and tuffs of Calico Hills, Crater Flat Tuff, and Lithic Ridge Tuff, all of Miocene Age (R. W. Spengler, U.S. Geological Survey, written commun., 1983). In addition to these formations, five bedded tuffs also were penetrated. These tuffs have a wide range of physical properties. They vary from nonwelded to densely welded, devitrified to vitric, and zeolitized to nonzeolitized. A detailed description of the drill cuttings is presented in Whitfield and others (1984). 


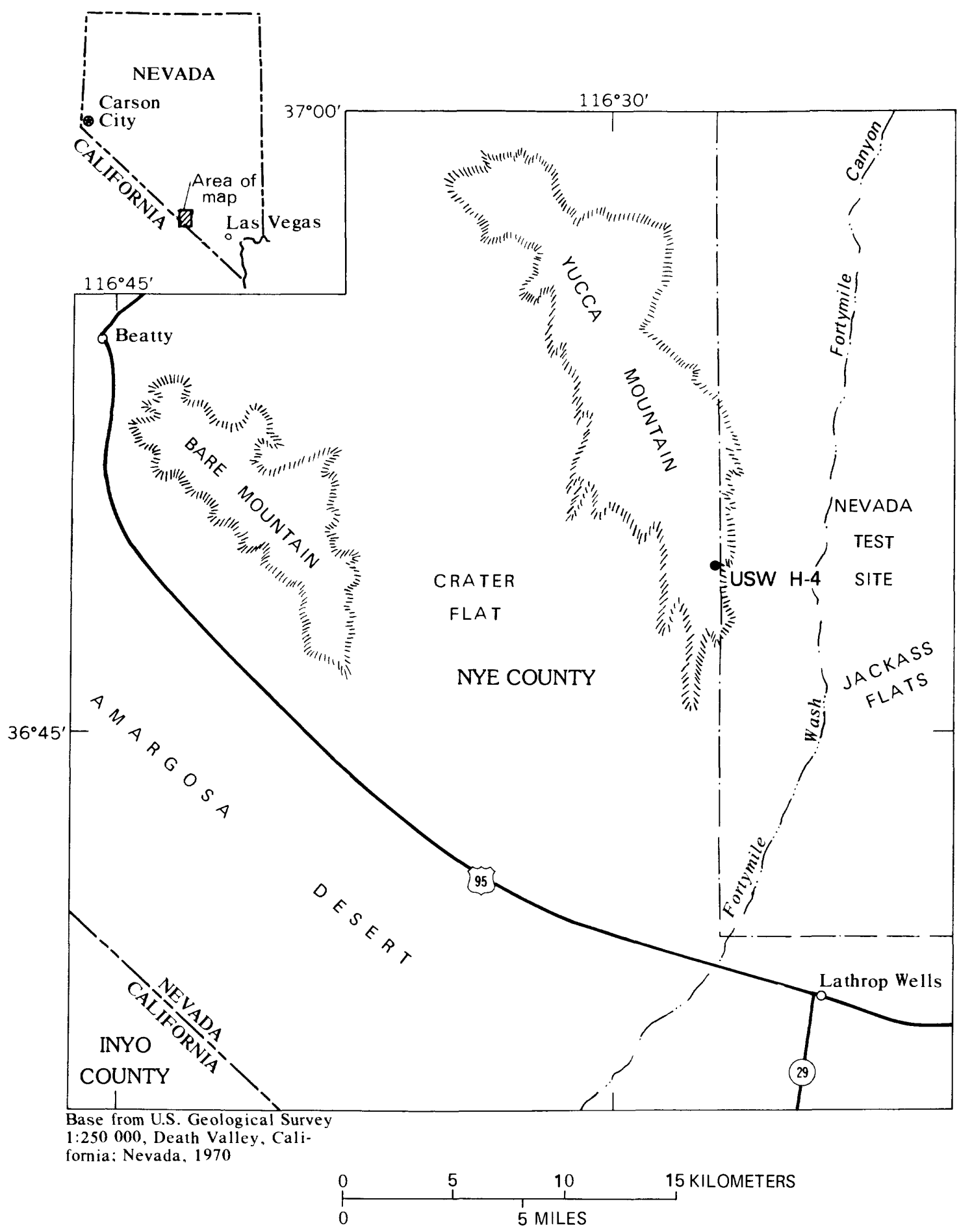

Figure 1.--Location of test well USW H-4. 
The tectonic history and structural geology of Yucca Mountain are complex. Yucca Mountain contains numerous faults. Most faults are westerlydipping normal faults, although easterly-dipping faults also are present (Lipman and McKay, 1965; Scott and Bonk, 1984). Northwest-striking, rightlateral, strike-slip faults of small displacement are present in the northwestern part of Yucca Mountain (Scott and Bonk, 1984). Fractures at Yucca Mountain were produced by two different processes. Some fractures were produced as a result of cooling, shortly after the tuffs were deposited. However, the majority of the fractures were a result of the tectonic processes that produced the large number of faults present at Yucca Mountain.

Yucca Mountain is within the Alkali Flat-Furnace Creek Ranch ground-water basin (Waddell, 1982). The general direction of ground-water flow in the basin is southerly toward two discharge areas, Alkali Flat about $40 \mathrm{mi}$ south of Yucca Mountain and Death Valley near the Furnace Creek Ranch about $35 \mathrm{mi}$ southwest of Yucca Mountain. Ground-water flow beneath Yucca Mountain is generally southward toward the Amagosa Desert.

\section{Well Construction}

Test well USW H-4 was rotary drilled with air foam, a drilling fluid consisting of air, detergent, and water, to a depth of 4,000 ft in April, 1982 (Whitfield and others, 1984). Casing (10-3/4 in. diameter) extends to 1,839 ft below land surface; the bottom $41 \mathrm{ft}$ were cemented. The casing was perforated from 1,749 to $1,768 \mathrm{ft}$. At the completion of drilling, the well was developed and cleaned by pumping. The composite depth to water below land surface was $1,703 \mathrm{ft}$ on May 22, 1982.

\section{Fracture Distribution and Orientation}

Data on fracture orientations, obtained from an acoustic-televiewer log of test well USW H-4, agree with the orientation of the faults in this area; from this $\log , 86.2$ percent of the identified fractures in the saturated zone have strikes ranging from $\mathrm{N} 10^{\circ} \mathrm{W}$ to $\mathrm{N} 55^{\circ} \mathrm{E}$, with dips ranging from $50^{\circ}$ to $86^{\circ}$. Lipman and McKay (1965) mapped five major normal faults, striking approximately $\mathrm{N} 10^{\circ} \mathrm{E}$, that cross the valley where test well USW H-4 is located (fig. 2). More recent detailed mapping of this area indicates approximately 20 normal high-angle faults cross this valley (Scott and Bonk, 1984).

A second set of fractures, oriented approximately $\mathrm{N} 15^{\circ} \mathrm{W}$ to $\mathrm{N} 55^{\circ} \mathrm{W}$, was identified with television-camera log (R. W. Spengler, U.S. Geological Survey, written commun., 1984); from this $\log 14.9$ percent of the fractures have strikes that range from $\mathrm{N} 15^{\circ} \mathrm{W}$ to $\mathrm{N} 55^{\circ} \mathrm{W}$; whereas, only 5.7 percent of all fractures identified with acoustic-televiewer log have strikes in this range. A possible explanation for this difference is that the apertures associated with northwest-trending fractures tend to be smaller than those associated with the north- to northeast-trending fractures; thus, northwest-trending fractures are not readily detected with the acoustic-televiewer log. Within the regional-tectonic stress field, the northwest-trending fractures are under compression (Carr, 1974), which would tend to close fractures oriented in this direction. 


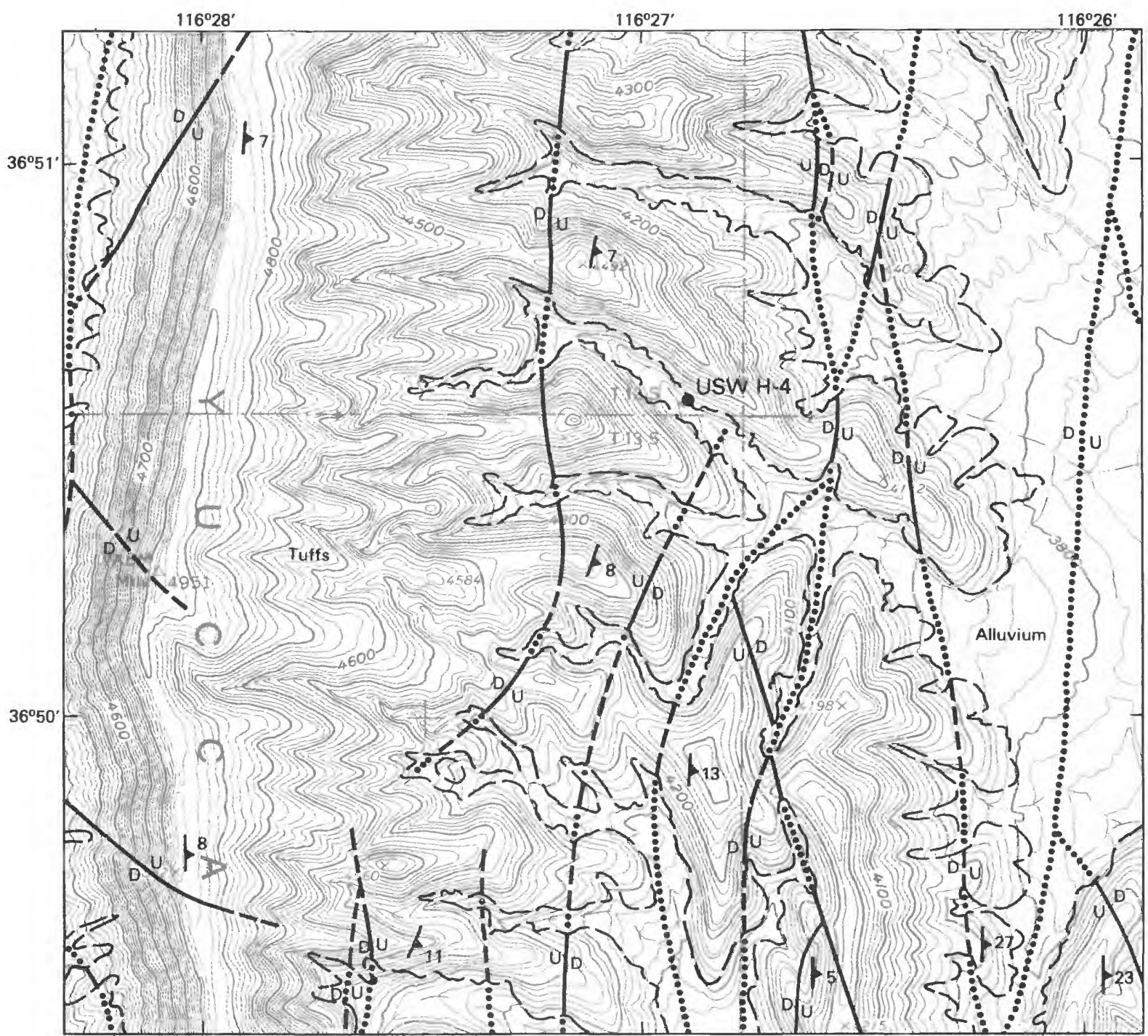

Base from U.S. Geological Survey

Busted Butte, Nev., guadrangle, 1983

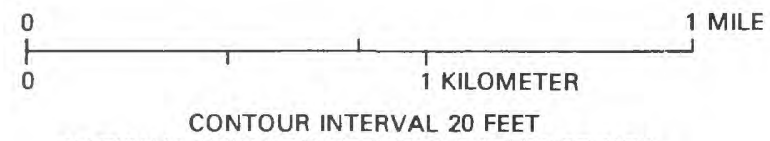

NATIONAL GEODETIC VERTICAL DATUM OF 1929

\section{EXPLANATION}

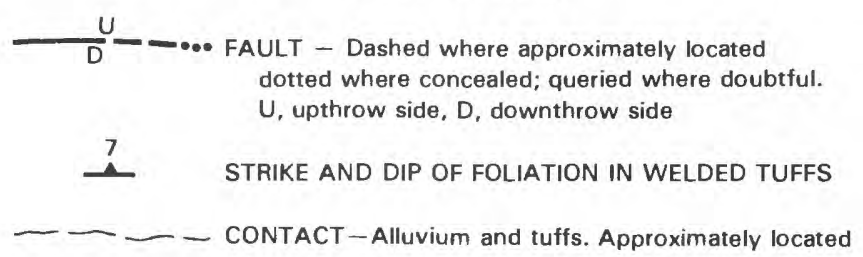

Figure 2.--Location of faults near test well USW H-4 (modified from Lipman and McKay, 1965). 
The orientation and location of fractures identified in the acousticteleviewer $\log$ are shown in figure 3, as well as the location of permeable zones identified by other techniques (which are discussed later). Fracture data are presented in this figure primarily to show their vertical distribution; a stereographic plot is presented in a later section. The convention used in the designation of the strike of a fracture is that the fracture dips in the direction $90^{\circ}$ clockwise from the given strike direction. For example, a fracture with a strike of north dips to the east. The acoustic-televiewer $\log$ was not useful for identifying fractures in intervals where the hole diameter was greater than 11 or $12 \mathrm{in.}$ These intervals are patterned in figure 3. In addition, other fractures were observed in the $\log$, but are not presented here, because their traces were incomplete and their orientations could not be determined. In most cases, these other fractures occurred in intervals that were densely fractured.

Most of the observed fractures occur in the interval from 2,290 to $3,000 \mathrm{ft}$. The interval from 3,000 to $3,885 \mathrm{ft}$ contains relatively few fractures; the borehole is smooth, with a diameter less than 10 in. throughout most of this interval, so that the data probably are representative of the fractures present. Below a depth of 3,885 ft, the acoustic-televiewer log was difficult to interpret, probably because of the rough character of the borehole wall. Three fractures were observed in this interval, and others were probably present.

Most of the fractures have strikes a few tens of degrees east of north, or west of south. Three northwest-trending fractures were observed in the depth interval from 2,900 to $2,950 \mathrm{ft}$. In many instances, east-dipping or west-dipping fractures occurred in separate groups. Examples are from 2,550 to 2,650 ft (east-dipping), and from 2,000 to 2,100 ft, from 2,375 to $2,440 \mathrm{ft}$, and from 2,780 to $2,850 \mathrm{ft}$ (west-dipping). Mixed groups of fractures occurred from 2,275 to $2,350 \mathrm{ft}$, and from 2,880 to 2,940 ft. This last group also contained shallower dipping fractures than occurred throughout most of the rest of the borehole.

\section{HYDRAULIC AND TRACER TESTS}

Various types of data are available for identification of permeable zones in USW H-4. Tests and logs run immediately after drilling was completed include three pumping tests, 15 straddle-packer injection tests, temperature surveys, and a radioactive-tracer flow survey (tracejector) during pumping, and geophysical logs (Whitfield and others, 1984). An acoustic televiewer log was run to aid in the identification of fractures. In January 1983, radioactive iodine ( $I-131$ ) was used as a tracer to measure vertical flow within the well and to determine location of fractures that were contributing to the vertical flow. 


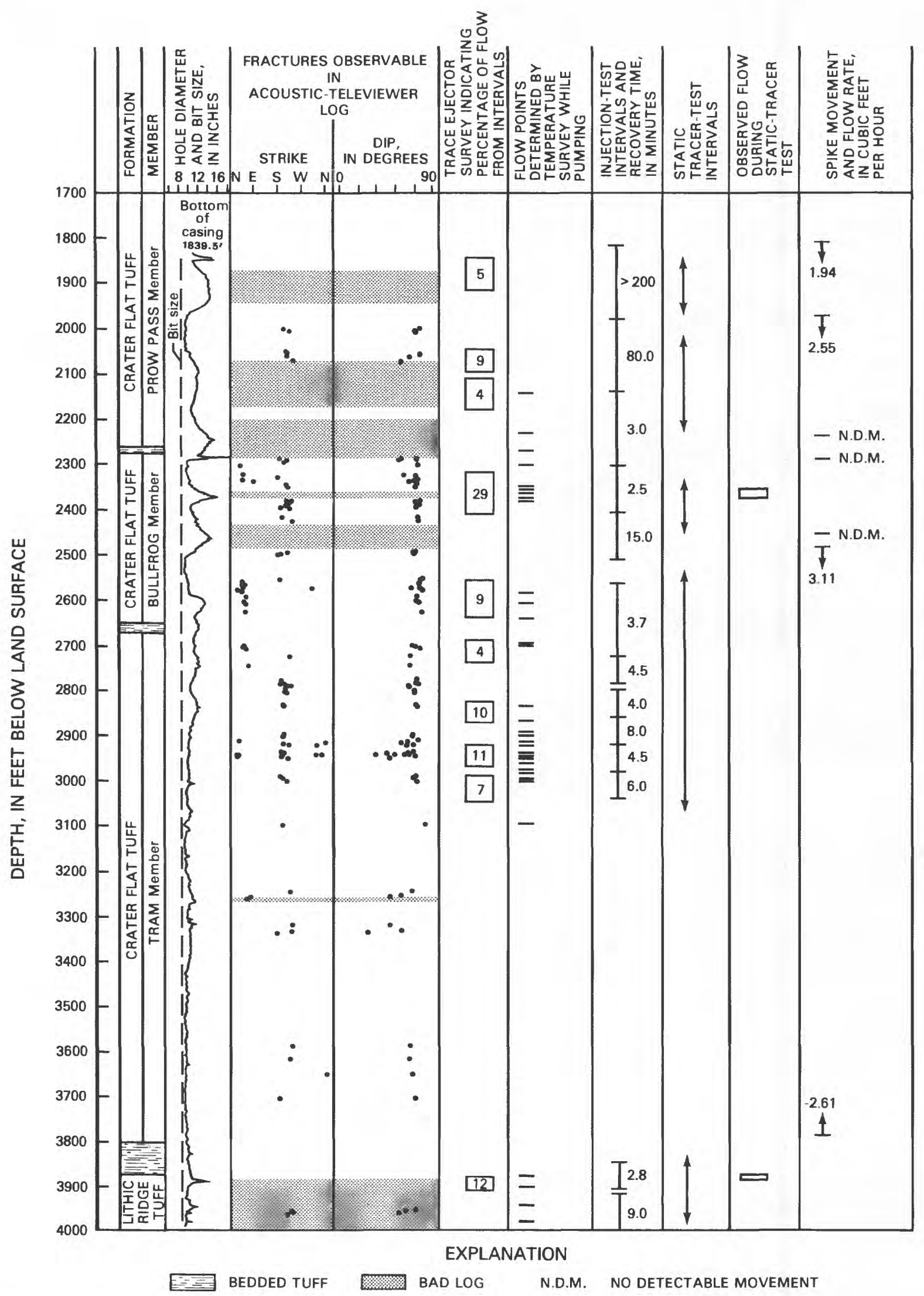

Figure 3.--Location of fractures and flow intervals identified by tracejector survey, temperature surveys, injection tests, and static-tracer tests in test well USW H-4. 


\section{Tests Under Pumping Conditions}

\section{Temperature Survey}

Temperature can be an indicator of heat transport. The two dominant mechanisms for heat transport in environments below the Earth's surface are conduction (or diffusion) and advection with a moving fluid. If the temperature distribution and thermal conductivities are known, the conductive flux can be readily calculated. If total thermal flux also is known, advective flux and, therefore, fluid velocity, also can be determined. Bredehoeft and Papadopulos (1965) presented an analytical solution for the simple case of vertical conductive and advective thermal transport through a layer with low permeability, from which vertical ground-water velocity can be calculated. Implicit in their assumptions is that no perturbations to either the temperature or hydraulic-potential field results from the measurement system, which includes the access well. Their results are, therefore, strictly applicable only to cases where no water flow can occur in the borehole. However, these results do show that, if the thermal conductivity of the rock does not vary greatly, the direction of fluid movement can be determined from the temperature profile. If the temperature profile is concave downward, fluid movement is upward. In addition, the greater the curvature, the greater the fluid velocity.

The temperature survey during pumping was used as a guide in determining where water was entering the well bore. Water temperature in the borehole at any point is determined by: (1) Temperature of the rocks surrounding the borehole, and the rate at which heat can move between the rocks and the water; (2) quantity of heat transported into or out of the borehole by water moving into or out of the borehole; (3) rate at which movement of water transports heat along the borehole; and (4) external sources of heat, such as a pump motor. If no water movement occurs in the borehole, the water temperature will equal the rock temperature and the temperature gradient will be fairly uniform. If, however, movement of water does occur (because of either hydraulic-head differences along the borehole, or presence of convective cells, due to temperature differences along the borehole), temperatures of the water in the borehole and the rock surrounding it will be different. Generally, and in the case of test well USW H-4, no independent measure of rock temperature is available. Without data on rock temperature, no unequivocal interpretation of temperature profile is possible. However, in a well that is being pumped, the advective transport of heat by water moving into and along the borehole dominates conductive transport, and identification of production zones is easily made.

Deviations from a linear-temperature profile generally indicate movement of water in the borehole. For example, consider a pumping well where the pump is located near the top of the saturated zone, and where all the water enters the borehole near the top of the saturated zone. The temperature profile in the borehole below the production zone would closely resemble the profile that would exist under nonpumping conditions (fig. 4, case 1 ). If, however, the production zone is located near the bottom of the borehole, the temperature profile would be much different (case 2). The temperature gradient just above the production zone would be nearly zero. Toward the top of the borehole, the gradient would increase, as heat is lost to the surrounding, cooler rock. In 


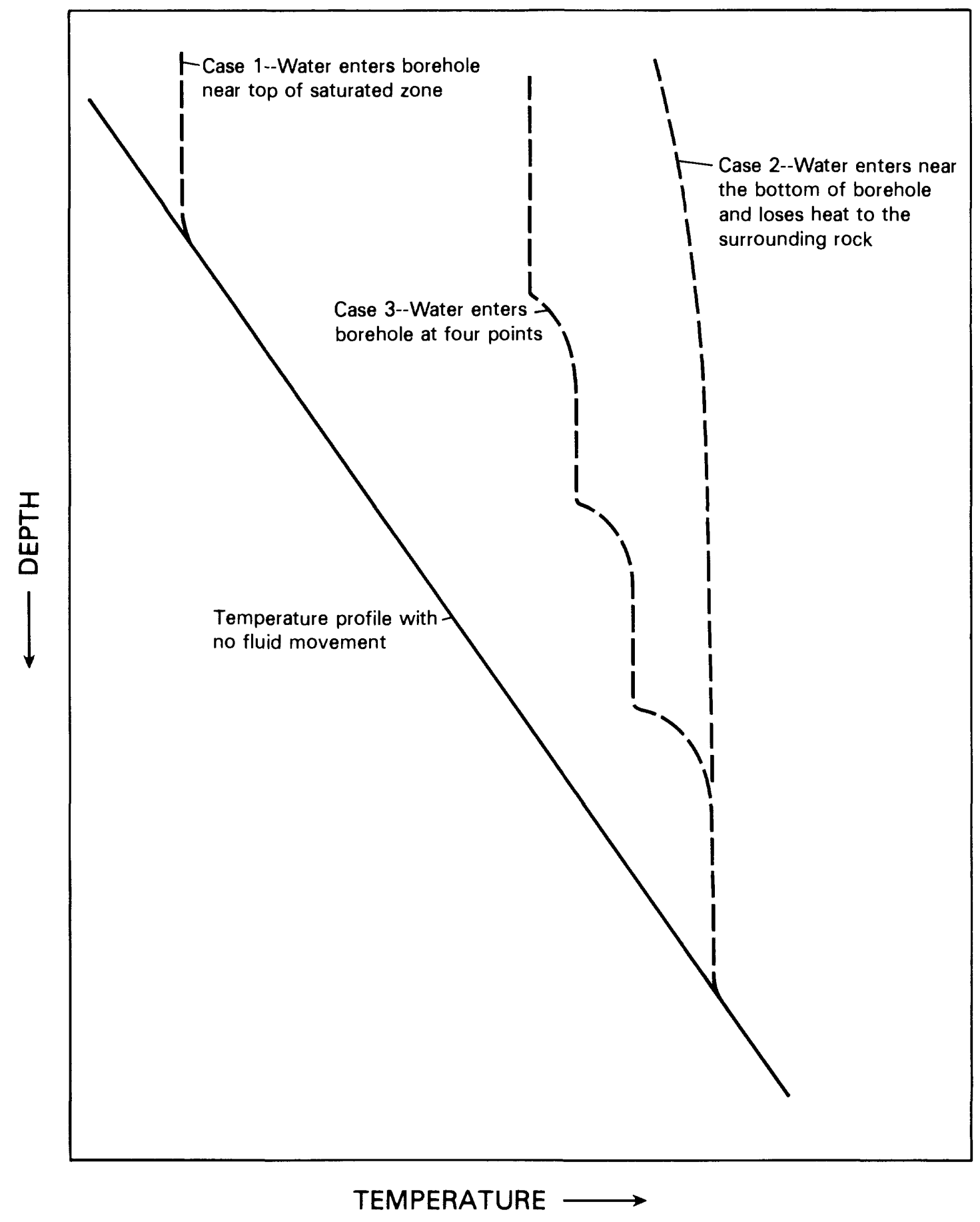

Figure 4.--Hypothetical temperature profiles in a borehole with upward-moving water being produced at various depths. 
a typical borehole, water enters the borehole in many places, and the temperature profiles discussed before are repeated many times (case 3 ). The magnitude of the gradient change is determined by: (1) Differences in temperature

between the water in the borehole and the water coming into the borehole; and (2) the ratio of the flow rate in the borehole to the flow rate of additional water that comes into the borehole. Quantification of incoming flow rates cannot be done without accurate measurements of water and rock temperatures, the latter of which were not available for test well USW H-4. Therefore, the temperature log during pumping conditions was used to identify the locations, but not the rates, of inflow.

The temperature profile and zones that produced water during pumping are shown in figure 5 . The depths are accurate to within about $\pm 5 \mathrm{ft}$, including uncertainty in interpreting the $10 \mathrm{~g}$ and errors in depth measurement. Errors in locating points of inflow, for zones that cause a large change in the temperature, are greater than for zones that cause a smaller change, because of the finite response time of the sensor and recording equipment.

Thirty-three separate inflow points were identified from the temperature logs. The interval from 3,110 to $3,880 \mathrm{ft}$ probably is devoid of distinct points of inflow; water may have entered the hole from the rock matrix, but not from fractures. Intervals containing zones that contributed flow are from 2,148 to $2,387 \mathrm{ft}$, from 2,590 to $2,706 \mathrm{ft}$, from 2,840 to 3,100 ft, and from 3,883 to $3,980 \mathrm{ft}$. The concave downward curvature of the temperature $10 \mathrm{~g}$ from 3,985 to $4,000 \mathrm{ft}$ indicates that flow may be coming from the bottom of the hole as well. Flow also was observed in the interval from 1,749 to $1,768 \mathrm{ft}$ where the casing was perforated. The temperature log shows that the increase in temperature caused by the pump motor $(1,730$ to $1,790 \mathrm{ft}$ ) was partially offset in the vicinity of the perforations by cooler water entering the borehole. However, the points or zones of entry of this water into the annular space between the casing and the wall of the hole are not known.

\section{Tracejector Survey}

A tracejector survey (radioactive-tracer flow survey) is a survey of water velocity and flow rate within a pumping well using a gamma-emitting tracer and two gamma detectors (Blankennagel, 1967). The tracer is ejected from the logging tool, and its movement in the hole is monitored by gamma detectors. This method assumes that the volumetric flow rate is the product of the velocity of the tracer and the cross-sectional area of the borehole, at the depth where the measurement is made. A tracejector survey provides a quantitative measure of water production in the borehole, but a tracejector survey is not as sensitive to the location of a production zone as a temperature survey. The tracejector survey (fig. 5) was run in USW H-4 during the same pumping test as the temperature survey (discussed before) (Whitfield and others, 1984).

Results of the tracejector survey, summarized in figure 3 , indicate that one interval (from 2,320-2,410 ft) contributed 29 percent of the pumped water in test well USW $\mathrm{H}-4$. The rock in this interval is a partially welded, ashflow tuff, within the Bullfrog Member of the Crater Flat Tuff. Five other intervals each contributed 9 to 12 percent of the flow, whereas four others 


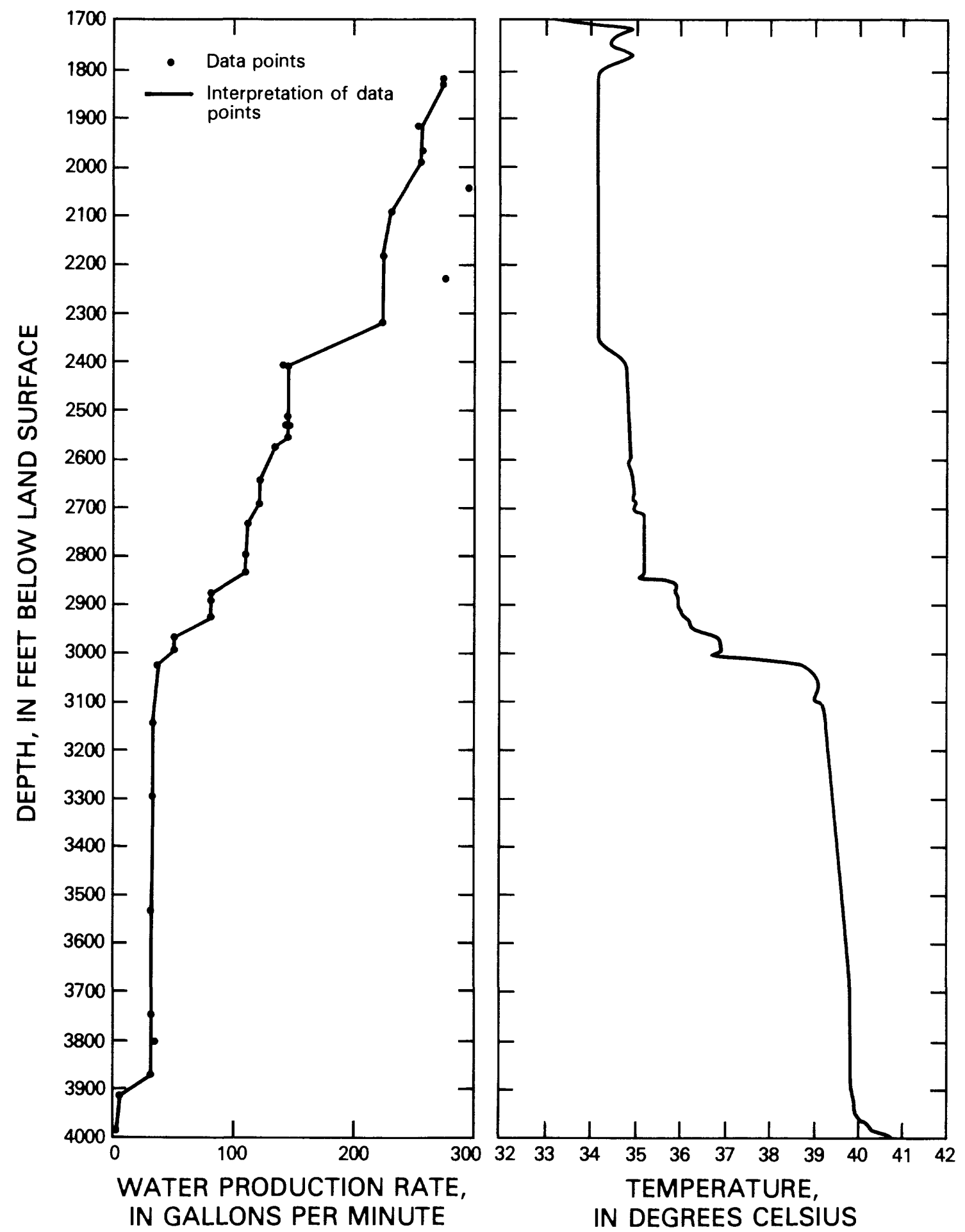

Figure 5.--Results of tracejector and temperature surveys while pumping test well USW H-4. 
contributed 4 to 7 percent. The flow surveys indicate that less than 21 percent of the total saturated section penetrated by test well USW H-4 contributed measurable quantities of water to the well bore. The remaining 79 percent of the saturated section either is not permeable enough to transmit measurable quantities of water or contains poorly connected fractures.

\section{Injection Tests}

Hydraulic injection testing was performed in intervals isolated by packers (Whitfield and others, 1984). After the packers were inflated, a valve immediately above the upper packer was opened, allowing water to drain from the tubing into the isolated interval. Although data on the hydraulic-head decline can be used to estimate the permeability of the isolated zone, they are used here to indicate only the relative permeability of the intervals. Intervals tested, using straddle packers, and the time required for the water level in the tubing to fall to the pretest level are shown in figure 3 , as determined from data presented in Whitfield and others (1984). Tests run when the packers were not set (no isolation of the injection zone from the rest of the borehole) indicate that about 2.5 to 3 minutes are required for water to drain through passages within the packer assembly. Tests that were completed in this length of time indicate that the isolated interval was quite permeable. Intervals where this occurred are from 2,306 to $2,411 \mathrm{ft}$, and from 3,851 to $3,910 \mathrm{ft}$. If the test required more than an hour or two, the isolated interval was relatively impermeable; long tests occurred in the intervals from 1,839 (bottom of casing) to $1,981 \mathrm{ft}$, and from 1,981 to $2,139 \mathrm{ft}$. The other zones tested had moderate permeabilities. The interval from 3,044 to $3,851 \mathrm{ft}$ was not tested.

\section{Tracer Tests under Nonpumping Conditions}

Although tests under pumping conditions and injection tests yield information on distribution of permeability within a borehole, these tests cannot provide information on rates and directions of water movement in the borehole under nonstressed conditions. Static (nonpumping) tests, using iodine-131 as a tracer, were used to provide these data. One part of this testing involved ejecting small quantities of the tracer at points where other test data indicated that water was not entering or leaving the borehole. The verticalvelocity of the water was obtained by monitoring the location of the tracer with time. The second part of the testing consisted of ejecting the tracer throughout intervals of tens to hundreds of feet, where water was thought to be entering or leaving the borehole, and monitoring the tracer's concentration. The resulting logs provided data on the location of zones where flow occurred under nonpumping conditions.

Static-tracer tests were conducted in test well USW H-4 in January 1983. The equipment used for the static-tracer tests consisted of an ejector for placing iodine-131 into the borehole and a gamma detector, both suspended on logging cable. A ratemeter was used to measure I-131 activity. An iodine-131 concentration of approximately $1 \mathrm{mCi} / \mathrm{mL}$ (millicurie per milliliter) was used in the ejector. Iodine-131 is virtually conservative, has a short half life (8.041 days), and emits gamma rays. Its activity is easily monitored in deep holes with readily available geophysical-logging equipment. 


\section{Tracer Spikes}

Spikes of iodine-131 were ejected above and below zones to be tested to determine the direction and rate of intrawell-bore flow (flow along the axis of the borehole). The lowermost spike was ejected and monitored first, to minimize the dispersion resulting from the logging cable and probe moving through it. All spikes and intervals were logged from bottom to top. Cable speeds, while logging through the tracer spikes and while moving back to the starting position for the next $\log$ run, were the same (about $20 \mathrm{ft}$ per min), to avoid spreading of tracer in one direction because of differences in $\log ^{-}$ ging rate. Spikes were monitored until direction was established, or until dispersion destroyed the shape of the spike. Spike locations were monitored for an average of 30 minutes, during which time three to seven logs of tracer activity were made.

Location of the center of mass of the tracer spike was determined by a trapezoidal-rule numerical integration routine. First, the total area under the curve was determined. The program then calculated the depth of the spike's center of mass. The first logging run through each spike was eliminated from the data set because the extreme, asymmetrical shape of the spike was an indication that the tracer was being moved up the hole by the tool, changing the distribution of the tracer during the first run. The ejector tool ejected the tracer into a small open volume within the cross-section of the tool, rather than laterally away from the tool. The tracer did not appear to actually leave the confines of the tool, until the tool was moved upward or downward. The extreme, asymmetrical shape of the spike disappeared after the first logging run, indicating that subsequent runs were not significantly affected by the ejector tool.

Vertical-flow velocities within the well bore were calculated by performing a linear regression between the center of mass and elapsed time since the first logging run through the spike. The slope of the regression line was the velocity. Analyses of variance were performed on results of the regressions to determine if tracer movement was detectable. The analysis of variance is equivalent to testing whether the slope of the regression line is significantly different from zero (Draper and Smith, 1981). A 90-percent confidence level was used to determine significance. For cases where movement was detected (that is, the slope of the line was significantly different from zero), the confidence level for the regression line was greater than 99 percent. Results of the linear regressions are presented in table 1.

Spikes were ejected at seven depths in test well USW H-4. Three of the spikes moved down hole; one spike moved up hole, and three spikes showed no detectable movement (table 1, fig. 3). Average intrawell-bore velocities ranged from undetectable to $5.42 \mathrm{ft} / \mathrm{h}$. Some of the variation in velocity resulted from changes in hole diameter. A more accurate measure of the true variation in flow was the average flow rate, which ranged from undetectable to $3.11 \mathrm{ft}^{3} / \mathrm{h}$ (table 1 ). 
Table 1.--Summary of tracer-spike velocities and flow rates

[Positive rates indicate downward movement; $\mathrm{ft}=\mathrm{foot} ; \mathrm{ft} / \mathrm{h}=\mathrm{feet}$ per hour; $\mathrm{ft}^{3} / \mathrm{h}=$ cubic feet per hour]

\begin{tabular}{|c|c|c|c|c|c|c|c|c|}
\hline \multirow[b]{2}{*}{$\begin{array}{l}\text { Spike } \\
\text { depth } \\
(\mathrm{ft})\end{array}$} & \multirow[b]{2}{*}{$\begin{array}{c}\text { Number of } \\
\text { logging } \\
\text { runs }\end{array}$} & \multicolumn{4}{|c|}{ Velocity $(\mathrm{ft} / \mathrm{h})$} & \multicolumn{2}{|c|}{ Flow Rate $\left(\mathrm{ft}^{3} / \mathrm{h}\right)$} & \multirow[b]{2}{*}{$\mathrm{R}^{2}$} \\
\hline & & Average & $\begin{array}{r}95 \\
\mathrm{co} \\
i\end{array}$ & $\begin{array}{l}\text { pe } \\
\text { fis } \\
\text { te }\end{array}$ & $\begin{array}{l}\text { ccent } \\
\text { dence } \\
\text { cva } 1\end{array}$ & Average & $\begin{array}{c}\text { 95-percent } \\
\text { confidence } \\
\text { interval }\end{array}$ & \\
\hline 1,817 & 5 & 3.55 & 2.24 & to & 4.86 & 1.94 & 1.22 to 2.65 & 0.949 \\
\hline 1,977 & 4 & 5.18 & 4.82 & to & 5.54 & 2.55 & 2.38 to 2.73 & .999 \\
\hline 2,244 & 3 & 3.33 & -18.49 & to & 25.14 & No det & cable movement ${ }^{1}$ & \\
\hline 2,294 & 4 & -.13 & -.92 & to & .66 & No det & cable movement ${ }^{1}$ & \\
\hline 2,465 & 3 & 2.50 & -3.24 & to & 8.28 & No det & able movement ${ }^{1}$ & \\
\hline 2,495 & 5 & 4.23 & 3.57 & to & 4.89 & 3.11 & 2.62 to 3.60 & .993 \\
\hline 3,798 & 3 & -5.42 & -3.41 & to & -7.43 & -2.61 & -1.64 to -3.58 & .999 \\
\hline
\end{tabular}

${ }^{1}$ Significance testing at the 90 -percent confidence level failed to reject the null hypothesis that the velocity was zero.

The uppermost point tested was within the casing below the perforations at a depth of $1,817 \mathrm{ft}$. The spike data indicated water was moving downward at $1.94 \pm 0.72 \mathrm{ft}^{3} / \mathrm{h}$. The $\mathrm{R}^{2}$ value for the regression was 0.949 , meaning that the regression equation explained 94.9 percent of the variation of the displacement of the center of mass with time. The downward movement of water was an indication that one or more flow zones existed between the water table $(1,703 \mathrm{ft})$ and the top of the cement $(1,798 \mathrm{ft})$.

The direction and rate of movement at a depth of $1,977 \mathrm{ft}$ was consistent with direction and rate at $1,817 \mathrm{ft}$. The direction of $\mathrm{flow}$ at $1,977 \mathrm{ft}$ was downward at a rate of $2.55 \pm 0.18 \mathrm{ft}^{3} / \mathrm{h}$. This $\mathrm{flow}$ rate was slightly faster than the flow rate determined above, and it was better-defined; that is, the 95-percent confidence interval was narrower for this spike than the spike above. The $\mathrm{R}^{2}$ value was 0.999 , which is an indication that the regression line was an excellent fit to the data. Overlap of the 95-percent confidence interval for the flux velocities at 1,817 and $1,977 \mathrm{ft}$ requires the use of additional statistical testing to determine if the fluxes are significantly different. Cochran and $\operatorname{Cox}$ (1957) present a t test for testing the equality of two population means when the variances are unequal. The results of this analysis indicate a difference in the flow rates for these depths at the 95-percent level. Hence, water is probably entering the borehole between $1,817 \mathrm{ft}$ and $1,977 \mathrm{ft}$.

Tracer spikes at 2,244 and 2,294 ft indicated no detectable movement. The 95-percent confidence interval for the velocity of the spike at $2,244 \mathrm{ft}$ was the largest interval determined for all seven spikes $( \pm 21.82 \mathrm{ft} / \mathrm{h})$. Velocity ranged from -18.49 to $25.14 \mathrm{ft} / \mathrm{h}$. The large confidence interval indicated that the regression for this spike was not significant, in agreement with the analysis of variance. Hence, the direction and rate that the spike 
was moving was indeterminate with the present data. In contrast to the confidence interval for the spike at 2,244 ft, the 95-percent confidence interval for the spike at $2,294 \mathrm{ft}$ was small, with the velocity ranging from -0.92 to $0.66 \mathrm{ft} / \mathrm{h}$. The narrow confidence interval was an indication that the velocity was well-defined and had a value of almost zero. The data for this case substantiated a near-zero velocity; whereas, for the former case, the data were inconclusive. Because the spikes were only $50 \mathrm{ft}$ apart, it is reasonable to assume that the flow rates at $2,244 \mathrm{ft}$ and $2,294 \mathrm{ft}$ were about zero. This condition indicates that the water moving down from above was leaving the well bore within the interval 1,977 to $2,244 \mathrm{ft}$.

Spike data at $2,465 \mathrm{ft}$ also failed to indicate direction and rate of water movement. The 95-percent confidence interval for the velocity ranged from -3.24 to $8.28 \mathrm{ft} / \mathrm{h}$. This large range indicates that the data were inconclusive and not necessarily that the velocity was almost zero.

The next spike was ejected at 2,495 $\mathrm{ft}$. The regression analysis of this data indicated water was moving downward at $3.11 \pm 0.49 \mathrm{ft}^{3} / \mathrm{h}$. The narrow range of the confidence interval and the large $R^{2}$ value $(0.993)$ was an indication that the flow rate was well-defined. Given that this spike was only $30 \mathrm{ft}$ below the previous spike at 2,465 ft and that the injection test data indicated a moderate permeability in this zone, it is reasonable to assume that the flow rate and direction at 2,465 $\mathrm{ft}$ may have been the same as at $2,495 \mathrm{ft}$. The flow rate at $2,495 \mathrm{ft}$ was greater than the flow rates determined at 1,817 and $1,977 \mathrm{ft}$.

The lowermost point tested was at a depth of $3,798 \mathrm{ft}$. The flow direction at this depth was upward at a rate of $2.61 \pm 0.97 \mathrm{ft}^{3} / \mathrm{h}$. This was the first location where an upward flow direction was measured. The $R^{2}$ value of 0.999 was an indication that the regression line was an excellent fit to the data. Pressure measurements of this lower zone further substantiated upward flow at this depth (Robison, 1984).

\section{Tracer Intervals}

In the second phase of testing, iodine-131 was ejected continuously while the logging tool was being lowered through the permeable zones identified by previous tests. A logging run was made of the zone immediately after ejection of tracer. Subsequent logs were made after periods ranging from minutes to hours. All intervals were logged while raising the logging tool. Logging speed ranged from 59 to $80 \mathrm{ft}$ per minute. The time constant on the rate meter was set at 1.5 seconds.

Identification of flow zones was done by visual comparison of several gamma logs for the interval and observing differences in the logs. Attempts to identify flow zones by subtracting digitalized logs from an arbitrarily defined reference $\log$ and by dividing logs into an arbitrarily defined reference $\log$ were unsuccessful. In general, the first $\log$ of an interval after ejection of the tracer contained peaks and troughs that did not appear to be related to hole diameter or water movement (fig. 6) and did not recur in subsequent logs. Therefore, the first log of an interval was never used. 


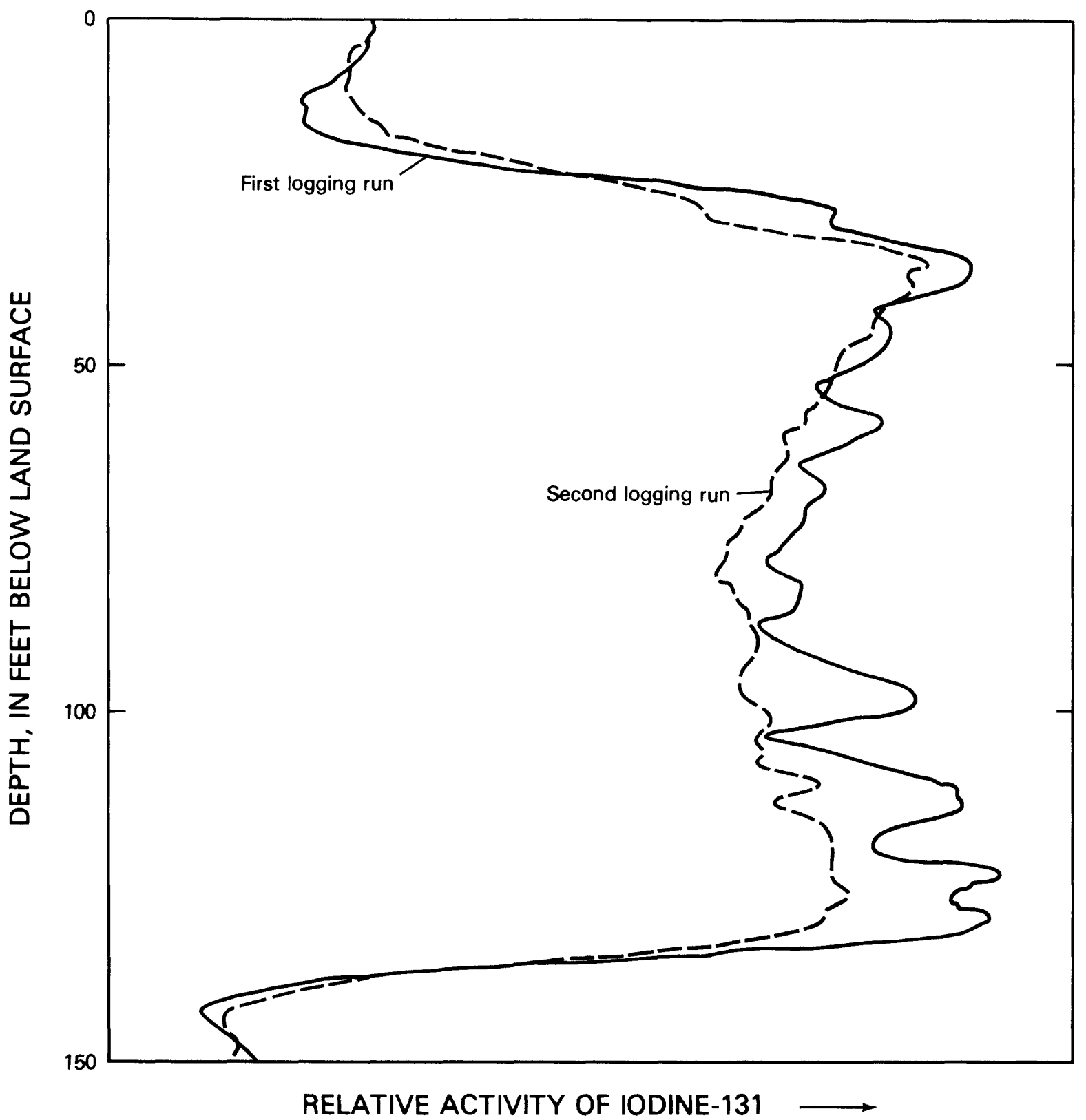

Figure 6.--Comparison between the first and second logging runs through a continuous-tracer interval in test well USW H-4. 
Significant dilution in tracer activity was the only feature that clearly indicated flow was occurring either into or out of a fracture. Development of peaks in tracer activity is not necessarily an indication of flow. Peaks of greater activity are an indication that more iodine-131 atoms are present at one location than adjacent to it, and such peaks commonly correlate with intervals of greater diameter and volume. Because the detector is sensitive to the number of iodine atoms and not the relative concentration, an enlarged section may have a greater total activity than a section next to it, when in fact the concentration of iodine in the enlarged section is actually less. No clear way is known of telling if movement of tracer into these enlarged sections results from natural flow or from mixing during logging.

Virtually all peaks that developed during testing in test well USW H-4 were in fractured sections of the borehole, where flow might be expected. However, the lack of significant dilution during the monitoring period prevented positive identification of flow zones in these areas.

The first zone tested was at a depth interval of 3,820 to $3,980 \mathrm{ft}$ below land surface ( $\mathrm{pl}, 1$ ). Nine logging runs were made through this interval during 10 hours, the longest monitoring period of all intervals tested in test we11 USW H-4. One flow zone was identified at a depth of $3,883 \mathrm{ft}$. Within the interval from 3,883 to $3,835 \mathrm{ft}$, a continuous dilution of tracer occurred with time, whereas, above this interval, tracer activity first increased and then decreased back to pretest levels. The increase in tracer activity above $3,835 \mathrm{ft}$ resulted from tracer moving up hole from the interval 3,883 to $3,835 \mathrm{ft}$. Below $3,883 \mathrm{ft}$, the tracer activity remained fairly constant, indicating that the direction of flow was upward from 3,883 ft, with no significant flow below this depth. The tracer spike just above this test interval also moved upward. Peaks in measured activity developed at depths of 3,828 , $3,885,3,919,3,930,3,943,3,955$, and 3,975 ft. Four out of the seven peaks developed in enlarged sections of the borehole. The remaining peaks may have formed as a result of tracer movement into fracture openings that were not recorded by the caliper log.

The tracer ejected throughout the interval from 2,540 to 3,070 ft was only slightly diluted during the 1.85 hours it was monitored (p1. 1). The monitoring period was too short to permit clear identification of flow zones. Upward movement of water appeared to have occurred at the lower boundary of the interval, consistent with the upward movement detected below. No clear indication of movement was detected at the upper boundary; spreading of the upper boundary probably was caused by the logging tool moving through it.

The third interval tested was from 2,330 to 2,450 ft; it was logged nine times during 3 hours ( 1 1. 1). Considerable dilution in tracer activity occurred throughout this entire interval, except for one location. A sharp peak developed at 2,374 $\mathrm{ft}$ and remained during the entire period this interval was monitored. However, unlike the sections immediately above and below, no dilution of tracer was associated with this peak. The location of this peak also corresponds to a large increase in borehole volume, indicating that this section is densely fractured and would be a likely candidate for flow. In general, tracer was moving downward throughout the entire interval. Downward flow also was determined with the tracer spike at 2,495 ft, $45 \mathrm{ft}$ below this test interval. Water appeared to be moving downward from about $2,330 \mathrm{ft}$, and 
into the formation between 2,365 and $2,375 \mathrm{ft}$; freshwater entered the borehole between 2,380 and $2,385 \mathrm{ft}$ and moved downward. This flow zone corresponds to the major producing zone identified with the temperature and radioactive-tracer flow survey.

The fourth interval tested was from 2,010 to $2,240 \mathrm{ft}$; it was logged six times during 2.25 hours. Little dilution was observed in this interval (p1. 1). Tracer movement on the upper boundary appeared to be downward, consistent with the direction of movement of tracer spikes above. Movement and spreading of the tracer on the lower boundary may have been the result of intrawell-bore flow or spreading by the logging tool. No movement of the tracer spike $4 \mathrm{ft}$ below this interval was detected.

The uppermost test interval was from 1,834 to $1970 \mathrm{ft}$; it was logged five times during 1.32 hours. Dilution of the tracer in this interval was slight during the monitoring period. Therefore, no flow zones were identified. The direction of tracer movement on the boundaries of this test interval was masked by the spreading that resulted from the logging tool.

\section{Correlation between Flow Points and Fractures}

The flow points identified from the temperature log during pumping correlated with the location of fractures. However, not all fractures identified in the well bore were associated with flow. The majority of the fractures had no detectable flow. Fractures were identified in test well USW H-4 with a combination of acoustic-televiewer logs and television-camera logs. The strike, dip direction, and magnitude of the dip could be determined from the acoustic-televiewer log, whereas, only the strike and dip direction could be determined with the television log. The acoustic-televiewer log was not accurate in sections of the hole that were enlarged, that is, where fractures might be expected to occur; hence, no fractures were observed in the acousticteleviewer $\log$ near many of the flow points. Table 2 shows depths and orientations of fractures within $\pm 5 \mathrm{ft}$ of the flow points that were identified with the temperature log. Among the fractures identified with the televisioncamera $\log$ that were within $\pm 5 \mathrm{ft}$ of the flow points, 83.1 percent had a strike direction of $\mathrm{N} 10^{\circ} \mathrm{W}$ to $\mathrm{N} 55^{\circ} \mathrm{E}$; only 9.6 percent were within the range of $\mathrm{N} 15^{\circ} \mathrm{W}$ to $\mathrm{N} 55^{\circ} \mathrm{W}$, less than the 14.9 percent of all fractures identified with the television-camera $10 \mathrm{~g}$ in the saturated part of the hole. Five flow points $(2,927,2,944,2,9882,998$, and $3,883 \mathrm{ft})$ were within $\pm 5 \mathrm{ft}$ of northwest-trending fractures.

Results of this fracture analysis indicate that water was produced predominantly from northeast-trending fractures. Whether this pattern was due to larger apertures associated with the northeast-trending fractures or due to a nonrepresentative sample of fractures penetrated by this borehole is not known. The flow point at 3,891 ft (tracer-interval depth 3,883 ft), which contributed most of the upward flow from the lower part of the hole while the hole was not being pumped, is dominated by northwest-trending fractures. This domination indicates a possible correlation between the upward flow at this depth and the northwest-trending fractures. 
Table 2.--Correlation of flow points, identified from temperature log obtained during pumping, with fractures identified from acousticteleviewer and television-camera logs

[Interval from top to bottom, in feet]

\begin{tabular}{|c|c|c|c|c|c|c|c|}
\hline \multirow{4}{*}{$\begin{array}{l}\text { Depth } \\
\text { of } \\
\text { flow } \\
\text { point } \\
\text { (feet) }\end{array}$} & \multicolumn{7}{|c|}{ Fractures } \\
\hline & \multicolumn{3}{|c|}{ Acoustic televiewer } & \multicolumn{4}{|c|}{ Television camera $^{1}$} \\
\hline & \multirow{2}{*}{$\begin{array}{l}\text { Depth } \\
\text { (feet) }\end{array}$} & \multirow[t]{2}{*}{ Strike } & \multirow[t]{2}{*}{ Dip } & $\mathrm{De}$ & feet) & \multirow{2}{*}{ Strike } & \multirow{2}{*}{$\begin{array}{r}\text { Dip } \\
\text { direc- } \\
\text { tion }\end{array}$} \\
\hline & & & & Top & Bottom & & \\
\hline
\end{tabular}

Interval 2,143-2,153

2,148

2,236

2,273

2,305

$2,307.0$

$\mathrm{N} 26^{\circ} \mathrm{E} \quad \mathrm{SE} 80^{\circ}$

None

2,216

2,229

2,246

2,238

$\stackrel{?}{\text { N }} \underset{70^{\circ}}{\mathrm{E}}$

?

Interval $2,268-2,278$

None

2,269

2,271

2,272

2,269

2,273

2,272

N $20^{\circ} \mathrm{E}$

$\mathrm{N} 65^{\circ} \mathrm{E}$

N $35^{\circ} \mathrm{E}$

SE

?

$\mathrm{SE}$

Interval $2,300-2,310$

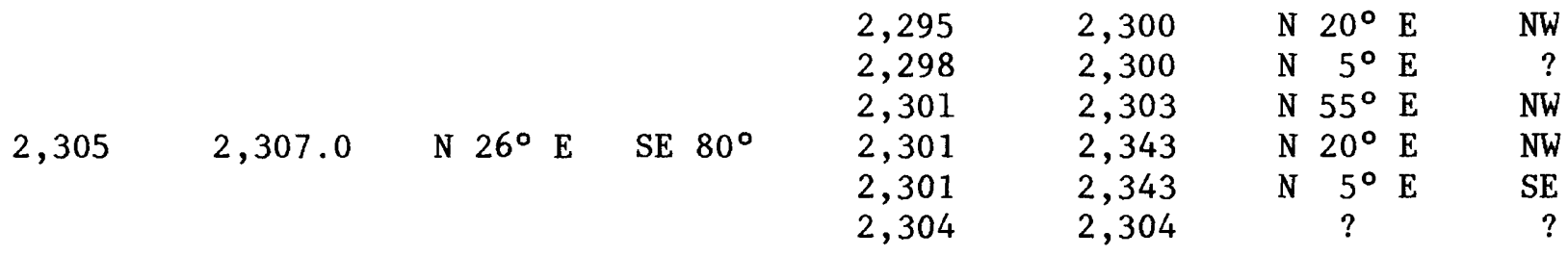

Interva1 2,348-2,369

\begin{tabular}{|c|c|c|c|c|c|c|c|c|c|}
\hline \multirow[b]{2}{*}{2,353} & $2,349.3$ & \multicolumn{2}{|c|}{$\mathrm{N} 20^{\circ} \mathrm{E}$} & $\mathrm{NW} 78^{\circ}$ & \multirow[b]{2}{*}{2,352} & \multirow[b]{2}{*}{2,353} & \multirow[b]{2}{*}{$\mathrm{N} 30^{\circ}$} & & \multirow[b]{2}{*}{ NW } \\
\hline & & & & & & & & $\mathrm{E}$ & \\
\hline & & & & & 2,353 & 2,356 & N $30^{\circ}$ & $\mathrm{E}$ & NW \\
\hline & & & & & 2,357 & 2,360 & N $30^{\circ}$ & $\mathrm{E}$ & NW \\
\hline & $2,356.5$ & N $29^{\circ}$ & $\mathrm{E}$ & NW $78^{\circ}$ & 2,357 & 2,360 & $\mathrm{~N} 15^{\circ}$ & $\mathrm{E}$ & NW \\
\hline 2,360 & & & & & 2,359 & 2,359 & N $20^{\circ}$ & $\mathrm{E}$ & NW \\
\hline 2,364 & & & & & 2,365 & 2,365 & N $20^{\circ}$ & E & NW \\
\hline & & & & & 2,363 & 2,366 & & E & SE \\
\hline & & & & & 2,363 & 2,366 & N $40^{\circ}$ & $\mathrm{E}$ & SE \\
\hline & & & & & 2,368 & 2,368 & $N 40^{\circ}$ & $\mathrm{E}$ & $?$ \\
\hline
\end{tabular}


Table 2.--Correlation of flow points, identified from temperature log obtained during pumping, with fractures identified from acousticteleviewer and television-camera logs--Continued

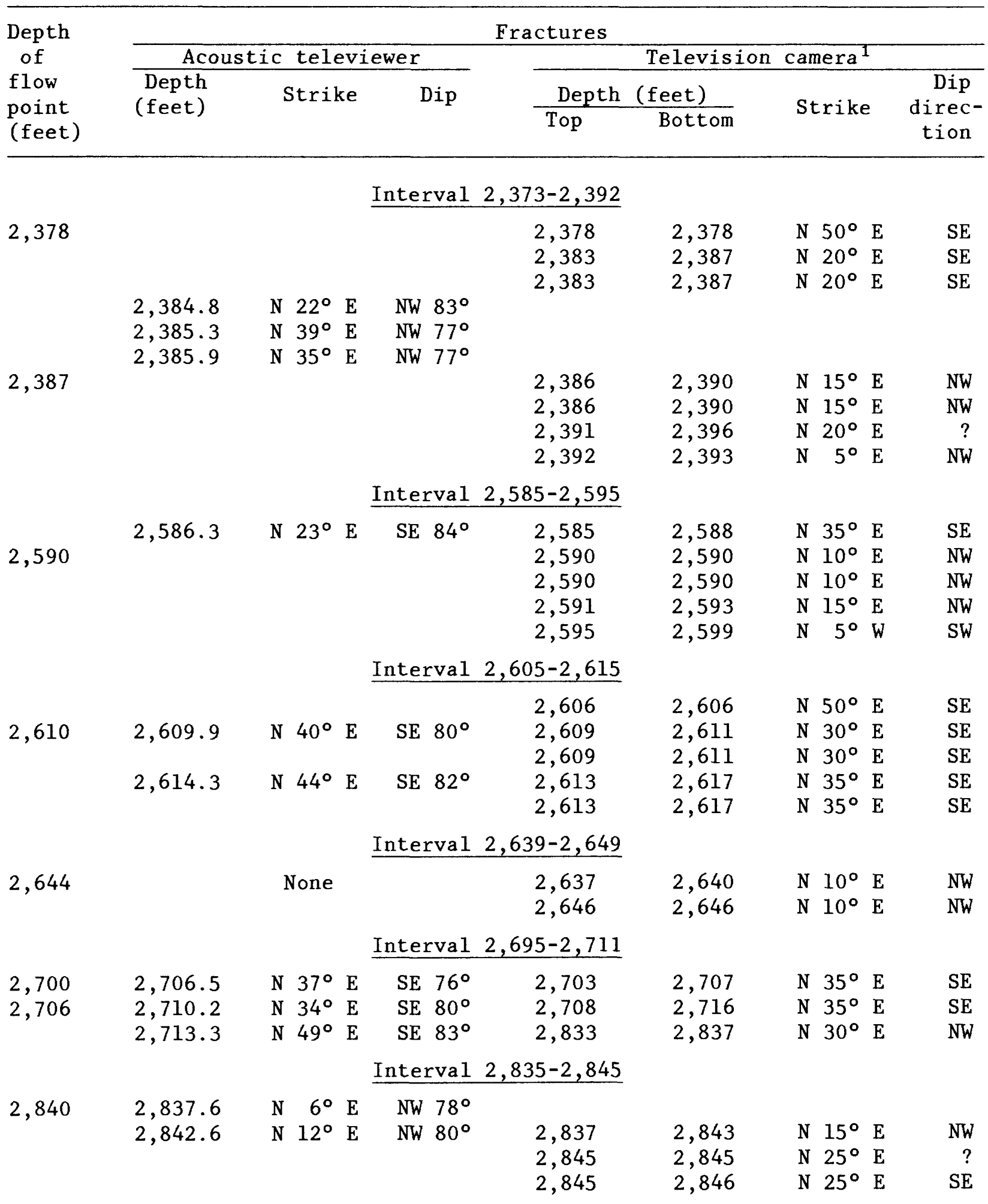


Table 2.--Correlation of flow points, identified from temperature log obtained during pumping, with fractures identified from acousticteleviewer and television-camera logs--Continued

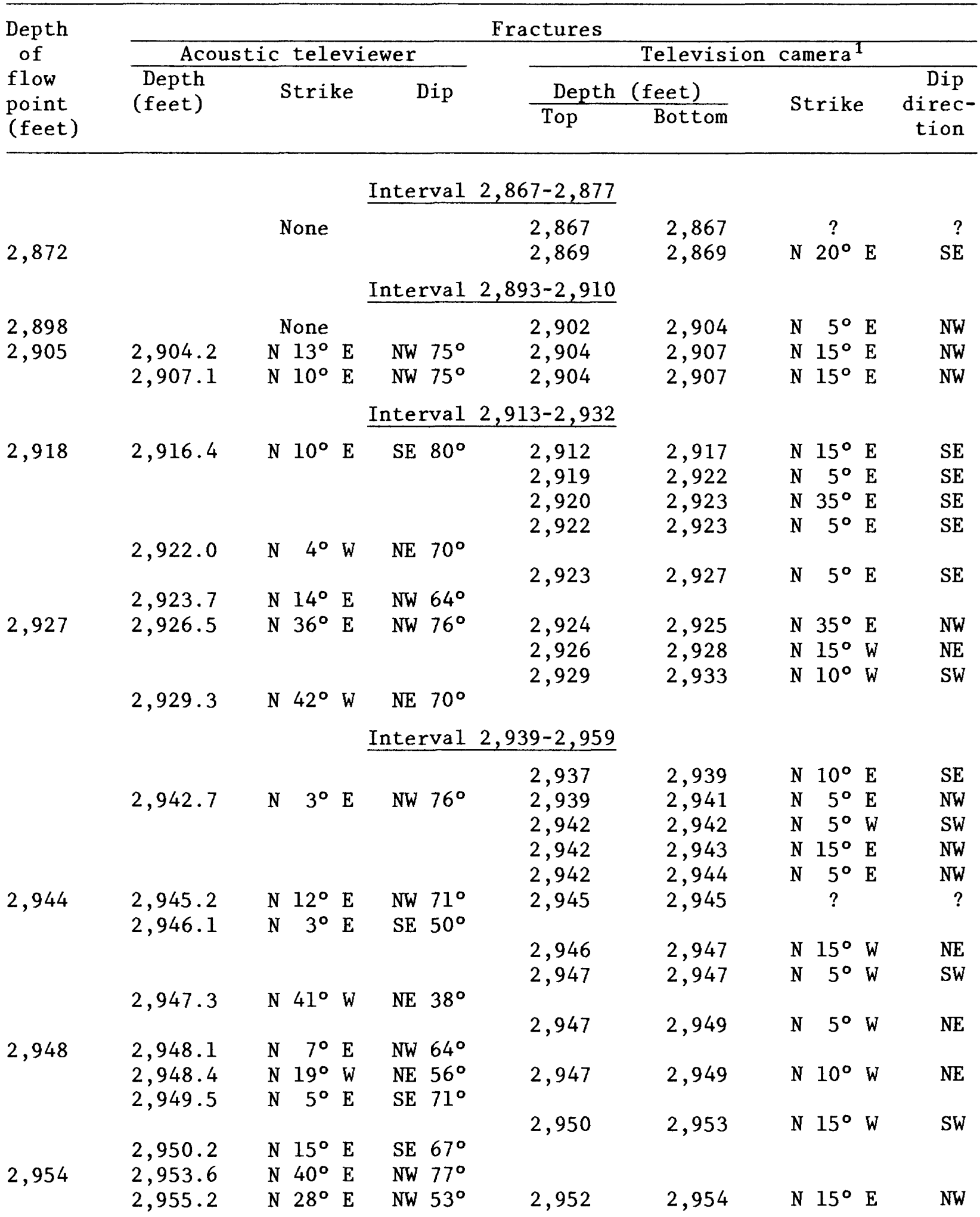


Table 2.--Correlation of flow points, identified from temperature log obtained during pumping, with fractures identified from acousticteleviewer and television-camera logs--Continued

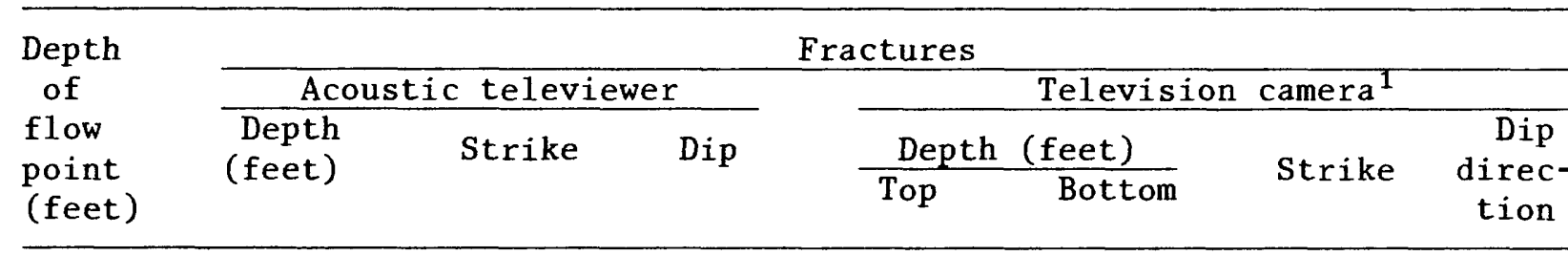

Interva1 $2,966-3,011$

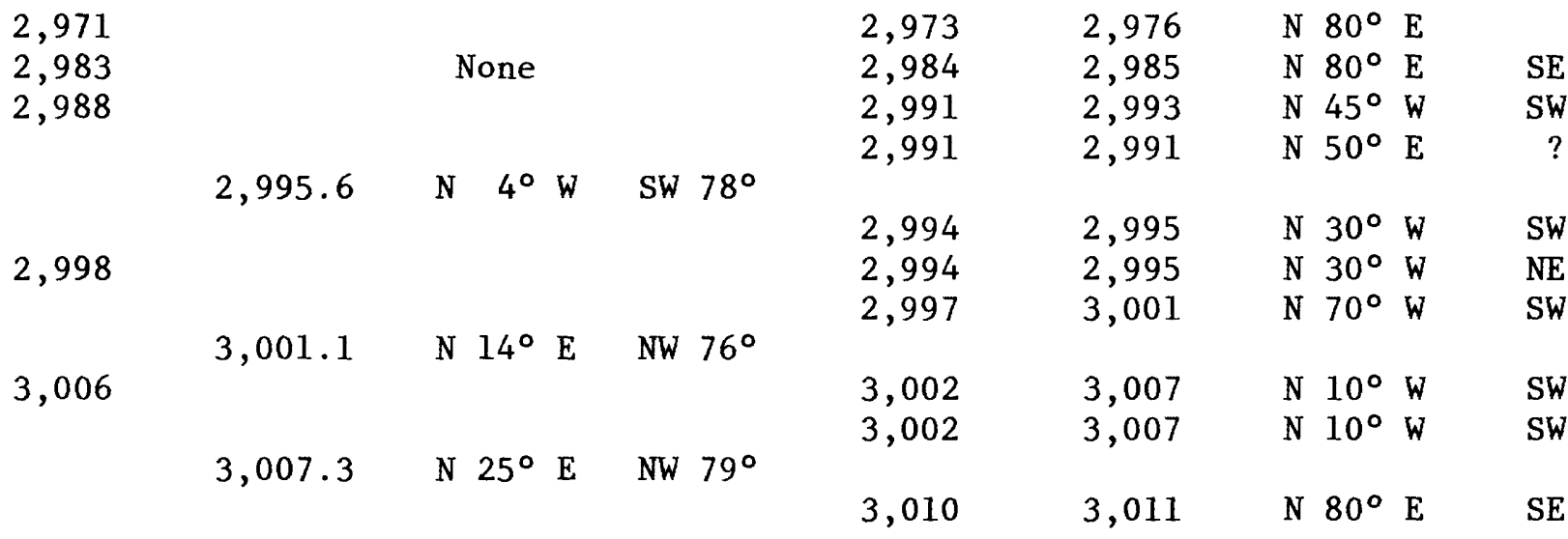

Interval $3,095-3,105$

$3,100 \quad 3,102.2 \quad \mathrm{~N} \quad 2^{\circ} \mathrm{E} \quad \mathrm{NW} 86^{\circ}$

$3,095 \quad 3,106 \quad \mathrm{~N} \quad 5^{\circ} \mathrm{W} \quad \mathrm{SW}$

Interva1 $3,886-3,896$

$3,891 \quad$ None

3,884

$3,886 \quad \mathrm{~N} 35^{\circ} \mathrm{E} \quad \mathrm{NW}$

$3,886 \quad 3,887 \quad \mathrm{~N} 45^{\circ} \mathrm{W} \quad \mathrm{SW}$

$3,886 \quad 3,887 \quad \mathrm{~N} 50^{\circ} \mathrm{W} \quad \mathrm{SW}$

Interva1 3,899-3,909

$3,904 ?$

None

None

Interva1 $3,939-3,949$

$\begin{array}{ccccr}3,938 & 3,941 & \text { N } 35^{\circ} & \mathrm{E} & \mathrm{NW} \\ 3,945 & 3,945 & ? & & ? \\ 3,949 & 3,950 & \mathrm{~N} 45^{\circ} \mathrm{E} & \mathrm{NW}\end{array}$

Interval $3,975-3,985$

3,980 None $\quad 3,970 \quad 3,975 \quad$ N $35^{\circ} \mathrm{E} \quad \mathrm{SE}$

${ }^{1}$ Television camera fracture data supplied by R. W. Spengler, 1984, U.S. Geological Survey. 
Two presumed flow points did not appear to have fractures associated with them. The existence of flow at these points $(2,148$ and $3,904 \mathrm{ft})$ is questionable because of the slight change in the temperature gradient associated with them, and they thus may not have contributed any significant flow.

\section{Summary of Test Results}

The combination of tests discussed above provides an understanding of permeability distribution and directions of flow within test well USW H-4. The tracer results indicate that, in the upper parts of the hole, water is moving downward, whereas, in the lower part, it moves upward. Experience gained from analyses of the static-tracer data indicates that: (1) An ejector of a different design (one that ejects out the side rather than into an open volume in the middle of the tool) might result in less initial spreading of spikes, and, therefore, make it possible to measure slower intrawell-bore velocities; and (2) continuous-ejection intervals need to be monitored for at least 4 to 6 hours.

Injection-test data indicate that the interval from $1,839 \mathrm{ft}$ (bottom of casing) to $2,140 \mathrm{ft}$ is relatively impermeable. Temperature data indicate this relatively impermeable zone extends to a depth of about 2,145 ft. These results are in contrast to the tracejector survey, which indicates that 14 percent of the discharge while pumping comes from this interval. The static tracer data are insufficient to resolve the apparent contradiction; a longer monitoring period of tracer activity would be required than was available. The tracejector data are suspect in this section of hole, because of turbulent flow resulting from changes in hole diameter. The injection-test data for this interval are probably reliable; the pressure responses during the tests (Whitfield and others, 1984) are what would be expected of lowpermeability rocks, and there was no indication that the testing equipment malfunctioned. The tracer data do indicate water was entering through the perforations and moving downward to a depth of 2,010 ft, and perhaps lower.

Injection-test data indicate that the interval from 2,140 to 2,305 $\mathrm{ft}$ is one of the more permeable intervals in the drill hole. Temperature data indicate four points in this interval where water entered the hole during the pumping test. The uppermost point $(2,148 \mathrm{ft})$ correlates with an interval that the tracejector survey indicated was providing a small quantity of water. Fractures corresponding to this point were not observed in either the television or acoustic-televiewer logs. The three other points were not detected in the tracejector survey; however, fractures were observed at depths corresponding to these three points. Flow zones were not identified in the tracer interval that overlaps with the upper part. of the injection test interval, possibly due to the short time that the interval was monitored.

The most permeable part of the hole occurs from 2,365 to 2,385 ft. The tracejector and temperature surveys, the injection tests, and the tracer tests all support this conclusion. Many northeast-trending fractures occur in this interval; no northwest-trending fractures were observed. Under nonpumping conditions, water probably moves into the interval from above, entering the borehole at depths between 2,294 (based on logs of the spike at 2,294 ft) and $2,330 \mathrm{ft}$. 
Downward flow continues to a depth of 2,495 ft, and perhaps below. Water movement was not detected on the upper boundary of the tracer ejection interval, 2,540 to 3,070 ft, perhaps because it was monitored for less than 2 hours. Water moved upward from the lower boundary during this period. The temperature log indicated that water entered the borehole during pumping from a minimum of 19 different depths within the interval 2,540 to 3,070 ft. Injection tests substantiated the moderate to significant permeability of this interval. About 41 percent of the production came from this interval, although it was not concentrated within as small an interval as that discussed in the previous paragraph. Where the water enters or leaves the borehole, and in which direction it flows, is not known, because of the brevity of the monitoring period during the static-tracer tests.

The tracejector and temperature surveys indicated that little water was entering the hole from 3,070 to $3,798 \mathrm{ft}$ while the hole was being pumped. A spike at 3,798 $\mathrm{ft}$ indicated upward movement under nonpumping conditions. Packer-injection and static-tracer tests were not conducted in this interval.

The interval from 3,891 to $4,000 \mathrm{ft}$ contains four depths that the temperature survey indicates produced water during pumping. The upper two depths $(3,891$ and $3,904 \mathrm{ft})$ correspond to a zone identified by the tracejector $\log$ as providing 12 percent of the production during pumping; these depths also correspond to the second most permeable zone $(3,850$ to $3,910 \mathrm{ft})$, identified by injection tests. During the static-tracer tests, water entered the hole at approximately 3,883 $\mathrm{ft}$ and moved upward. The discrepancy in depth between the tracer $\log$, and the temperature and tracejector logs is probably due to lack of accuracy in depth-measuring equipment.

In summary, water is moving vertically in the hole toward the interval between about 2,500 and 3,070 ft, corresponding to the lower part of the Bullfrog Member and upper part of the Tram Member of the Crater Flat Tuff. An instance was observed where water was moving down and out of the hole (from 2,365 to $2,375 \mathrm{ft}$ ), presumably along a fracture zone with low hydraulic head. A few feet farther down the hole, other (non-tracer bearing) water entered the hole (from 2,380 to 2,385 ft), and moved downward. In general, good correlation exists between zones determined to be permeable by different techniques; however, no single technique was capable of producing sufficient information to characterize distribution of permeability and direction of movement within the borehole.

\section{HYDRAULIC-CONDUCTIVITY ELLIPSOID}

Darcy's law describing the three-dimensional flow of water through a nonhomogeneous anisotropic porous medium, written in matrix notation is:

$$
\mathrm{q}=\mathrm{K} \cdot \mathrm{J}
$$

where $q=$ the specific discharge vector, $\mathrm{L} / \mathrm{T}$;

$\mathrm{K}=$ the hydraulic conductivity tensor, $\mathrm{L} / \mathrm{T}$; and

$\mathrm{J}=$ the hydraulic gradient vector, dimensionless.

For an anisotropic porous medium, the hydraulic-conductivity tensor has nine components. If the coordinate axes are alined with the principal hydraulicconductivity directions, the number of components is decreased to three. 
Equation 1 was derived for a porous medium; however, it can be applied to a fractured medium, if an equivalent hydraulic-conductivity tensor can be determined for the fractured medium. Snow (1969) derived an equation to determine this tensor. This equation is based on the solution to the NavierStokes equation for laminar flow between two parallel plates; it further assumes all fractures from a given set are parallel, infinite in extent, and have a constant aperture. Snow's equation usually is applied by first determining the total number of fracture sets present in the data and calculating an average fracture for each set. The use of average values for the fracture sets masks the true variation in fracture orientation, thereby biasing the orientation of the permeability ellipsoid. However, the assumption can be made that each fracture is from a different fracture set, whose spacing is equal to the length of the sampling line, thereby incorporating the total distribution of fracture orientations into the hydraulic-conductivity tensor. The term, sampling line, as used in this report, is the distance between the first fracture encountered in the saturated zone and the bottom of the borehole. The equation used to calculate the hydraulic-conductivity tensor in matrix notation, is:

$$
K_{i j}=\frac{2 b_{f}{ }^{3} \gamma_{w}}{3 L_{f} \mu_{w}}\left[\begin{array}{lll}
1-n_{1}{ }^{2} & -n_{1} n_{2} & -n_{1} n_{3} \\
-n_{2} n_{1} & 1-n_{2}{ }^{2} & -n_{2} n_{3} \\
-n_{3} n_{1} & -n_{3} n_{2} & 1-n_{3}
\end{array}\right]
$$

where $b_{f}=$ one-half the aperture of the fracture, $L$;

$\gamma_{w}=$ the specific weight of water, $M / L^{2} T^{2}$;

$\mathrm{L}_{\mathrm{f}}=$ the fracture spacing normal to the fracture plane, $\mathrm{L}$;

$\mu_{w}=$ the dynamic viscosity of water, M/LT; and $n^{1}, n^{2}, n^{3}=$ the unit normal vectors for the fracture plane.

Matrix permeability is assumed to be equal to zero. The hydraulicconductivity tensor has nine components and is symmetrical. The eigenvectors of this tensor give the orientations of the principal directions, and the eigenvalues are the principal hydraulic conductivities (axes lengths squared of the hydraulic-conductivity ellipsoid). In test well USW $\mathrm{H}-4$, orientations of fractures are known, but not their apertures. By assuming arbitrary values for fracture apertures, the orientation and eccentricity of the ellipsoid could be determined, though the values of hydraulic conductivity would have no real significance. In this study, eccentricity is expressed as the ratio of the smallest principal hydraulic conductivity to the greatest one.

Fracture orientations used in the Snow analysis were determined from the acoustic-televiewer log. The acoustic-televiewer log does not detect as many fractures as the television-camera log. This limitation is most apparent in table 2. The acoustic-televiewer detects small changes in distance from the logging tool to the borehole wall. In order for the acoustic televiewer to detect a fracture, the fracture must have a small relief developed along it. The smaller the fracture aperture becomes, the more likely the acousticteleviewer will not detect it. The television camera is not as severely limited by the size of the aperture. Of the total number of fractures identified by the acoustic-televiewer $\log , 5.7$ percent were northwest-trending 
(N $15^{\circ} \mathrm{W}$ to $\mathrm{N} 55^{\circ} \mathrm{W}$ ) fractures, whereas 14.9 percent of all fractures identified with the television-camera $\log$ were northwest-trending, a factor of 2.6 more. This difference indicates that the apertures of the northwest-trending fractures may, on average, be smaller than the apertures of the northeasttrending fractures. To compensate, the aperture for the northwest-trending fractures was increased by the cube root of 2.6 , which is equivalent to adding more northwest-trending fractures to the data set. This procedure assumes that the northwest-trending fractures identified by the acoustic-televiewer $\log$ are representative of the population. This correction was applied to all cases discussed below.

The first hydraulic-conductivity ellipsoid calculated was for an equal aperture case, in which all fractures were assumed to have the same aperture. The plane containing the two largest principal axes of the hydraulicconductivity ellipsoid strikes $\mathrm{N} 22^{\circ} \mathrm{E}$ and dips $85.0^{\circ} \mathrm{NW}$. This plane is alined with the dominant northeast fracture set, as would be expected (fig. 7). The ratios of principal hydraulic-conductivity values are presented in table 3 . Two of the hydraulic-conductivity values are nearly equal, whereas, the third value is approximately an order of magnitude smaller.

A second analysis was made with the assumption that the northwesttrending fractures were closed. The plane defined by the two larger hydraulic-conductivity axes is oriented $\mathrm{N} 23^{\circ} \mathrm{E}$, with a dip of $84.6^{\circ} \mathrm{NW}$ (fig. 7). The net effect of assuming that the northwest-trending fractures were closed was to rotate this plane $1^{\circ}$ more to the east. The ratios of principal hydraulic-conductivity values for this case are nearly the same as in the previous case, indicating that the northwest-trending fractures are not significant in determining the orientation of the ellipsoid, when their apertures are equal to or smaller than the northeast fractures.

The final hydraulic-conductivity ellipsoid was calculated for the case where the northwest-trending fracture apertures were set equal to twice the value of the apertures of the northeast-trending fractures. The plane defined by the two principal axes is oriented $N 11^{\circ} \mathrm{E}$ with a dip of $89.8^{\circ} \mathrm{NW}$ (fig. 7 ). The ratios of principal hydraulic-conductivity values for this case are more affected by the change in aperture than in the previous case. The ratio of the minor and major hydraulic conductivities increased by a factor of 2.2. Data from the acoustic-televiewer and television-camera logs indicate that the northwest-trending fractures probably have a smaller aperture than northeasttrending fractures and data from the temperature survey and tracer work indicate the northwest-trending fractures are less likely to transmit water. Therefore, results of this analysis give an upper limit to the orientation of the principal hydraulic-conductivity axes.

Table 3.--Ratio of principal hydraulic-conductivity values for fractures in USW $\mathrm{H}-4$, as determined by the Snow equation

\begin{tabular}{cccc}
\hline \multicolumn{2}{c}{ Relative aperture values } & \multicolumn{2}{c}{ Ratio } \\
\hline NE & $\mathrm{NW}$ & $\mathrm{K}^{2}: \mathrm{K}^{1}$ & $\mathrm{~K}^{3}: \mathrm{K}^{\mathbf{1}}$ \\
\hline 1.0 & 0.0 & 0.949 & 0.131 \\
1.0 & 1.0 & 0.943 & 0.182 \\
1.0 & 2.0 & 0.797 & 0.396 \\
\hline
\end{tabular}




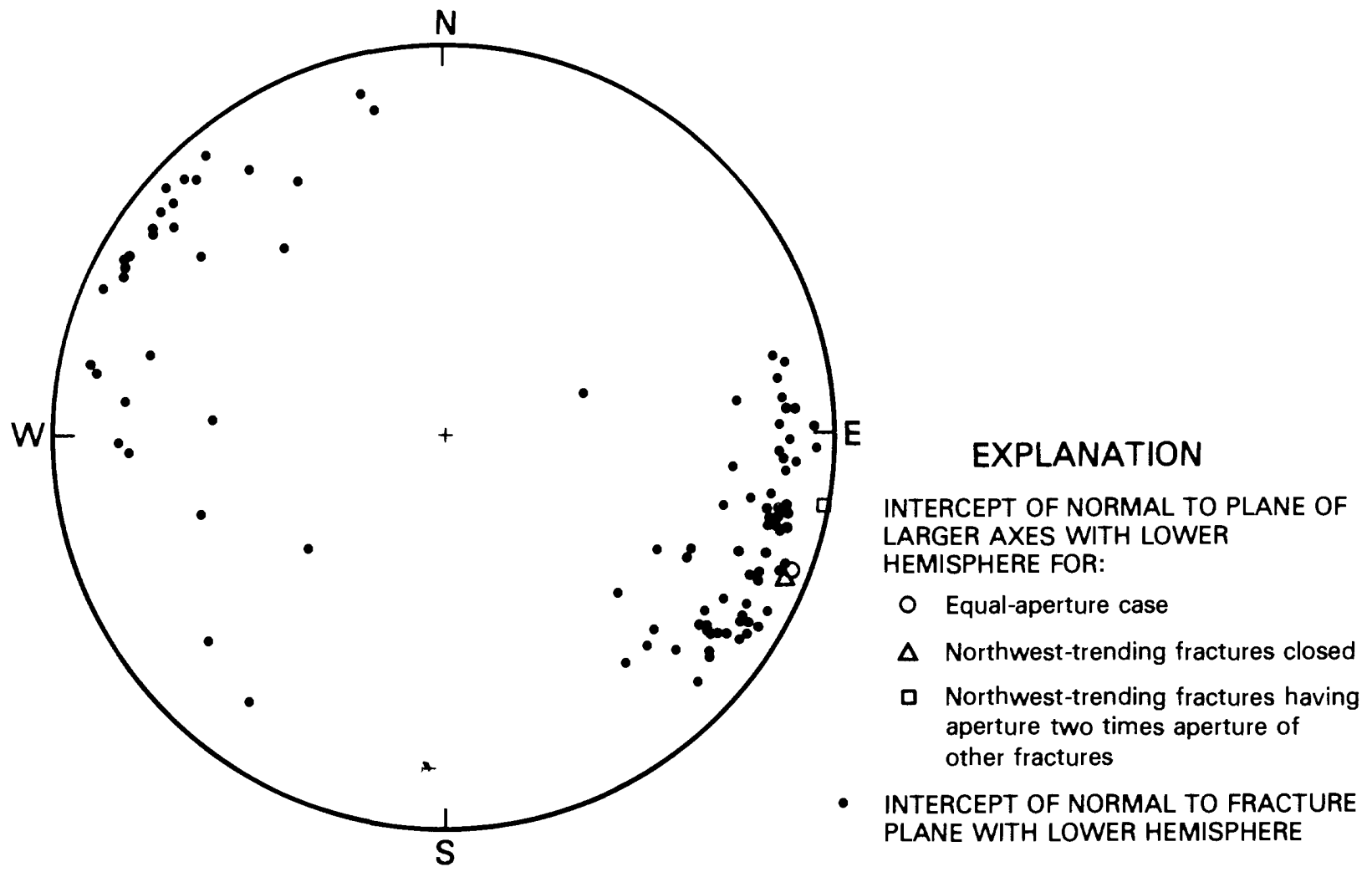

Figure 7.--Lower hemisphere, equal-area stereographic plot of fractures identified by acoustic-televiewer $\log$ in test well USW $\mathrm{H}-4$ and the plane containing the two major principal hydraulic-conductivity axes for equaland nonequal-aperture cases.

Results of the Snow analysis give a qualitative indication of the probable range of orientations for the principal hydraulic-conductivity axes. If the aperture for the northeast-trending fractures is equal to the aperture for the northwest-trending fractures, then the plane defined by the two larger principal hydraulic-conductivity axes is approximately alined with the northeast-fracture set. If the northwest-trending fractures are closed and nonconductive, the plane defined by the two larger principal axes is rotated slightly to the east. However, for the extreme case, where the apertures for the northwest-trending fractures are twice those of the northeast fractures, the plane defined by the two larger principal axes is rotated $11^{\circ}$ west of the plane for the equal aperture case. The dip of the plane for all these cases remained approximately the same. 


\section{FRACTURE POROSITY}

Effective porosity relates average pore velocity to Darcian velocity and is best determined through carefully controlled tracer tests. The tracer tests described above were not intended specifically for this purpose. However, data on fracture orientation, frequency from television and acousticteleviewer surveys, and the number of producing zones can be used to estimate fracture porosity of the rock mass. If most of the water moves in the fractures rather than through the rock matrix, then fracture porosity is a reasonable estimate of effective porosity. Fracture porosity probably is greater than effective porosity, because of the irregular topology of fracture walls and variations in the apertures of fractures from point to point and fracture to fracture.

The procedure used to calculate fracture porosity consisted of the following steps. First, the equivalent fracture aperture was calculated by dividing the estimated transmissivity in USW H-4 (M. S. Whitfield, U.S. Geological Survey, written commun., 1984) by the number of production zones, as determined by the temperature log during pumping, then calculating the aperture from the cubic law for flow between parallel plates. In this analysis, it was assumed that each point of production was due to a single fracture, and that all such fractures possessed the same aperture and have equal permeability. Next, the orientations of all fractures determined from the acousticteleviewer $\log$ were used to estimate the correction factor for samplingfrequency error caused by the high-dip angle of the fractures relative to the borehole. This correction factor was determined by summing the inverses of the cosine of the dip angle of each fracture, and dividing the sum by the number of fractures (Snow, 1969, p. 1278). The resulting correction factor was 5.17. The correction factor times the number of producing zones is an estimate of the number of producing fractures that would have been intercepted by the borehole if all fractures were perpendicular to the borehole. The aperture of the fractures times the corrected number of fractures, divided by the length of borehole along which production was determined, is the fracture porosity.

An empirical roughness coefficient is commonly employed to account for deviations in flow rate from the solution for smooth plates. In this study, arbitrary values of roughness coefficient [1.0 (smooth plate), 0.1 , and 0.01$]$ were used to determine the effect of this uncertainty on estimates of fracture porosity. M. S. Whitfield (U.S. Geological Survey, written commun., 1984) reported estimates of transmissivity ranging from 2,152 to $8,500 \mathrm{ft}^{2} / \mathrm{d}$. Cases using the two extremes were calculated. Results are presented in table 4. According to these calculations, fracture porosity is about 0.0001 to 0.001 , and effective porosity is the same, or less.

Table 4.--Estimates of fracture porosity of tuffs penetrated by USW H-4, assuming the 33 flow zones are equally permeable.

\begin{tabular}{ccc}
\hline \multirow{2}{*}{$\begin{array}{c}\text { Roughness } \\
\text { coefficient }\end{array}$} & \multicolumn{3}{c}{ Assumed transmissivity $\left(\mathrm{ft}^{2} / \mathrm{d}\right)$} \\
\cline { 2 - 3 } 2,152 & \multicolumn{3}{c}{ Fracture porosity } \\
\hline 1.0 & $1.1 \times 10^{-4}$ & $1.8 \times 10^{-4}$ \\
0.1 & $2.5 \times 10^{-4}$ & $3.9 \times 10^{-4}$ \\
0.01 & $5.3 \times 10^{-4}$ & $8.4 \times 10^{-4}$ \\
\hline
\end{tabular}




\section{SUMMARY AND CONCLUSIONS}

Test well USW H-4 was tested by various techniques. Combined results indicate that the distribution of productive zones within the well is not uniform. A large interval from approximately 3,105 to 3,890 ft probably is devoid of permeable fractures. Almost one-third of the water produced during the pumping test came from a depth of 2,365 ft. Thirty-three production points were identified in the temperature log obtained during pumping. Production probably is from single or small groups of fractures in each interval.

Monitoring of an iodine-131 tracer placed at selected points and through selected intervals indicated that, under nonpumping conditions, water is moving downward from above, and upward from below, toward the interval 2,500 through 3,070 ft, with the water leaving the borehole somewhere within this interval. The two zones where water was observed entering or leaving the borehole correspond to the most permeable intervals identified by injection tests of isolated intervals. Measured flow velocities ranged from 3.5 to $5.4 \mathrm{ft} / \mathrm{h}$; where the regression analysis indicated that flow velocity was lower, the regression was not statistically significant. Measurement of slower velocities probably could be done by using an ejector that did not trap the tracer within the confines of the tool, but ejected it out away from the tool. Intervals probably need to be monitored for several hours to detect movement in zones of lower permeability.

Production zones obtained from the pumping temperature log were associated with fractures observable in the television log or the acousticteleviewer $\log$, with the exception of two zones where interpretation of the temperature log was tenuous. In general, permeability is greater in parts of the borehole that are more densely fractured. More fractures striking north to northeast occur than ones striking northwest, so it is not surprising that the more permeable fractures are in the north-to-northeast group.

Estimation of the orientation of the hydraulic-conductivity ellipsoid at USW H-4, using the technique proposed by Snow (1969) and orientations of fractures determined from the acoustic-televiewer log, indicate that the plane containing the two larger principal hydraulic conductivities strikes approximately $23^{\circ}$ east of north; that these two hydraulic conductivities are nearly of equal magnitude; and that they are 5 to 7 times larger than the smallest principal hydraulic conductivity. The northwest-striking fractures have little effect on the ellipsoid. The hydraulic-conductivity ellipsoid gives an estimate of the anisotropy in the vicinity of the well. Fracture porosity is about $10^{-4}$ to $10^{-3}$ and approximates effective porosity.

The results presented in this report indicate that in detail the groundwater flow characteristics of the fractured tuffs at Yucca Mountain are complex. However, the methods used at test well USW H-4 can be applied at other test wells to aid in understanding the ground-water flow system at the Yucca Mountain site. Hydraulic-conductivity ellipsoids and effective-porosity values can be used in conjunction with hydraulic-head data to calculate ground-water flow directions, fluxes, and velocities. 


\section{REFERENCES CITED}

Blankennagel, R.K., 1967, Hydraulic testing techniques of deep drill holes at Pahute Mesa Nevada Test Site: U.S. Geological Survey Open-File Report, $12 \mathrm{p}$.

Bredehoeft, J.D., and Papadopulos, S.S., 1965, Rates of vertical ground-water movement estimated from the Earth's thermal profile: Water Resources Research, v. 1, no. 2, p. 325-328.

Carr, W.J., 1974, Summary of tectonic and structural evidence for stress orientation at the Nevada Test Site: U.S. Geological Open-File Report 74-176, $53 \mathrm{p}$.

Carr, W.J., Byers, F.M., Jr., and Orkild, Paul P., 1984, Stratigraphic and volcano-tectonic relations of Crater Flat Tuff and some older volcanic units, Nye County, Nevada: U.S. Geological Survey Open-File Report 84-114, $42 \mathrm{p}$.

Cochran, W.G. and Cox, Gertrude, 1957, Experimental design, (2d ed.): John Wiley, New York, $611 \mathrm{p}$.

Draper, N.R., and Smith, H., 1981, Applied regression analysis (2d ed.): John Wiley, New York, $407 \mathrm{p}$.

Lipman, P.W., and McKay, E.J., 1965, Geologic map of the Topopah Spring southwest quadrangle, Nye County, Nevada: U.S. Geological Survey Geological Quadrangle Map GQ-439, scale 1:24,000.

Maldonado, Florian, and Koether, S.L., 1983, Stratigraphy, structure, and some petrographic features of tertiary volcanic rocks at USW G-2 drill hole, Yucca Mountain, Nye County, Nevada: U.S. Geological Survey Open-File Report 83-732, 83 p.

Robison, J.H., 1984, Ground-water level data and preliminary potentiometricsurface maps, Yucca Mountain and vicinity, Nye County, Nevada: U.S. Geological Survey Water-Resources Investigations Report 84-4197, 8 p.

Scott, R. B., and Bonk, Jerry, 1984, Preliminary geologic map of Yucca Mountain with geologic sections, Nye County, Nevada: U.S. Geological Survey Open-File Report 84-494, scale 1:12,000, 3 sheets.

Snow, D.T., 1969, Anisotropic permeability of fractured media: Water Resources Research, v. 5, no. 6, p. 1273-1289.

Waddel1, R.K., 1982, Two-dimensional, steady-state model of ground-water flow, Nevada Test Site and vicinity, Nevada-California: U.S. Geological Survey Water-Resources Investigations 82-4085, $72 \mathrm{p}$.

Whitfield, M.S., Thordarson, William, and Eshom, E.P., 1984, Geohydrologic and drill-hole data for test well USW H-4, Yucca Mountain, Nye County, Nevada: U.S. Geological Survey Open-File Report 84-449, 39 p. 